\title{
ARQUEOLOGÍA DEL DISTRITO DE OCROS: ASENTAMIENTOS DEL PERIODO INTERMEDIO TARDÍO EN LA MICROCUENCA DEL RÍO QAQAMARCA, VALLE DE CHUMBES - AYACUCHO.
}

\author{
ANUOR ABEL GARCÍA REYES ${ }^{1}$ \\ UNIVERSIDAD NACIONAL MAYOR DE SAN MARCOS \\ agarey14@gmail.com
}

\section{RESUMEN}

El presente artículo discute los resultados del trabajo de prospección arqueológica realizado en la microcuenca del río Qaqamarca - valle de Chumbes, distrito de Ocros, Huamanga en 2008, como parte del Curso de Prácticas pre-profesionales. Los datos que exponemos a continuación están relacionados a los asentamientos del Periodo Intermedio Tardío (Chanca), cuyas tradiciones culturales revelan un conocimiento tecnológico constituido $\mathrm{y}$, por ende, nos hallamos frente a una cultura bastante compleja. Su patrón arquitectónico refleja una planta circular de disposición aglutinada asociada a entierros individuales y colectivos, y sistemas defensivos; el material cerámico hallado está relacionado al alfar Chanca. En síntesis, el estudio de las tradiciones culturales de este periodo es complejo, y por ello, el presente estudio ofrece un aporte más acerca de la ocupación Chanca en la cuenca baja del río Pampas.

Palabras Clave: Periodo Intermedio Tardío - Chanca - patrón de asentamiento - tradiciones culturales - microcuenca del río Qaqamarca - valle de Chumbes.

\section{AbSTRACT}

This article discusses the results of archaeological survey work conducted in the watershed of Qaqamarca River - Valley Chumbes, Ocros district, Huamanga in 2008, as part of the course of pre-professional practices. The data presented below relate to settlements of the Late Intermediate Period

1. Licenciado en Arqueología, Universidad Nacional de San Cristóbal de Huamanga. Maestrista en Gestión del Patrimonio Cultural, Universidad Nacional Mayor de San Marcos. 
(Chanca), whose cultural traditions reveal an established technological knowledge and therefore, we are faced with a very complex culture. Its architectural pattern reflects a circular arrangement bonded associated with individual and collective burial ground, and defensive systems; the found ceramic pottery is related to Chanca. In short, the study of the cultural traditions of this period is complex, and therefore, the present study provides a contribution more about Chanca occupation in the lower basin of the Pampas river.

KeYWoRDS: Late Intermediate Period - Chanca - settlement pattern - cultural Traditions - microcuenca the river Qaqamarca - valley Chumbes.

\section{INTRODUCCIÓN}

El presente artículo está referido a los resultados obtenidos en los trabajos de reconocimiento arqueológico en la microcuenca del río Qaqamarca - valle de Chumbes, ubicada en el distrito de Ocros, provincia de Huamanga, región de Ayacucho. Las labores de campo se efectuaron a finales del año 2008 como parte del curso de prácticas pre-profesionales, donde registramos un total de 30 asentamientos situados en diversos pisos ecológicos; identificando una secuencia de larga ocupación ininterrumpida desde el Periodo Lítico hasta la implantación de grandes haciendas coloniales. Como parte de esta investigación, los datos que exponemos a continuación están relacionados específicamente a los asentamientos del Periodo Intermedio Tardío (Rowe 1956), conocidos en el lenguaje arqueológico como los Chancas.

El proceso cultural prehispánico en la microcuenca del río Qaqamarca es poco conocido, debido a la escasa información científica afín a la arqueología, por lo que existen pocas referencias científicas que analicen de manera global la problemática social del Periodo Intermedio Tardío (PIT). Esta investigación aborda la problemática de la ubicación de los asentamientos y el reto de dominar la agreste geografía andina, y en base a estas perspectivas intentamos explicar e interpretar las formaciones sociopolíticas del PIT, las características particulares del patrón de asentamiento, material cultural de superficie, etc. Sin embargo, tendremos algunas limitaciones al intentar explicar ciertos aspectos sociales de los Chancas, por trabajar con material recogido de superficie, lo cual advierte la necesidad de realizar estudios sistemáticos con secuencias estratigráficas y fechados radio carbónicos.

En general, las investigaciones relacionadas al Periodo Intermedio Tardío abordan desde una perspectiva de índole superficial y pocos sitios han sido excavados sistemáticamente, lo cual ha generado controversia al momento de caracterizar la distribución de los asentamientos y la tipología del material cerámico. Los datos etnohistóricos refieren que inmediatamente antes de la conquista incaica, la formación política-social que ocupó la cuenca baja del Río Pampas y ambas márgenes del río Qaqamarca fueron los Chancas.

\section{Características Geográficas y Medioambientales DE la Microcuenca del Río Qaqamarca. UBICACIÓN DEL ÁREA DE ESTUDIO}

La microcuenca del río Qaqamarca está ubicada en la margen izquierda de la cuenca baja del rio Pampas, a $124 \mathrm{~km}$. al sureste de la capital de la región, y a una altitud relativa desde 1,900 a 4,200 m.s.n.m. Políticamente pertenece al distrito de Ocros, provincia de Huamanga y región de Ayacucho. El río Qaqamarca, cuya naciente se ubica al noreste del centro poblado de Ccaccamarca, orienta su recorrido de oeste a este y discurre sus aguas en el río Pampas. Existe en este extenso valle siete comunidades campesinas, cada uno con sus respectivos anexos y caseríos los cuales son: Ccaccamarca, Santa Isabel de Chumbes, San José La Colpa, Pajonal, Vacahuasi, Cusi y Ninabamba. 


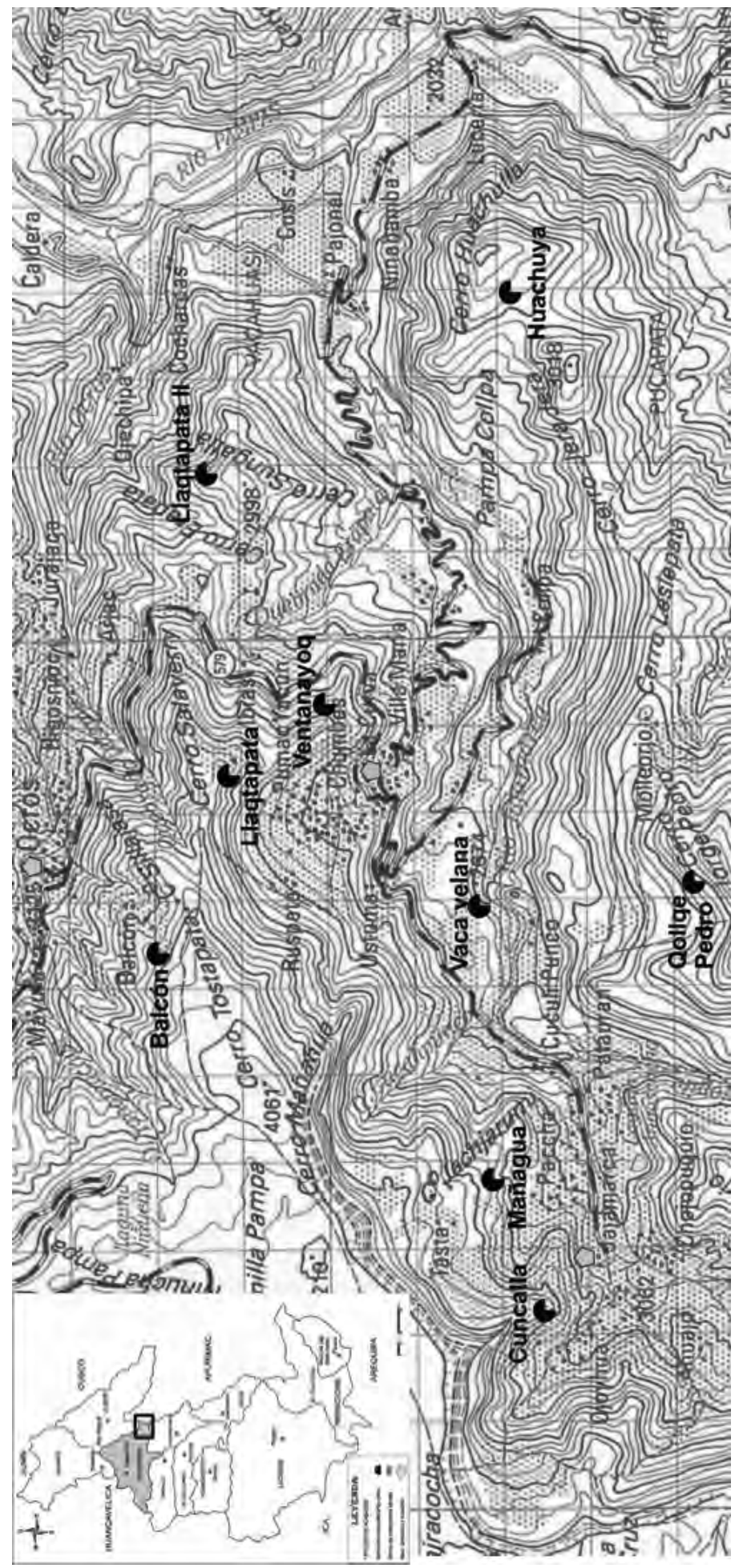




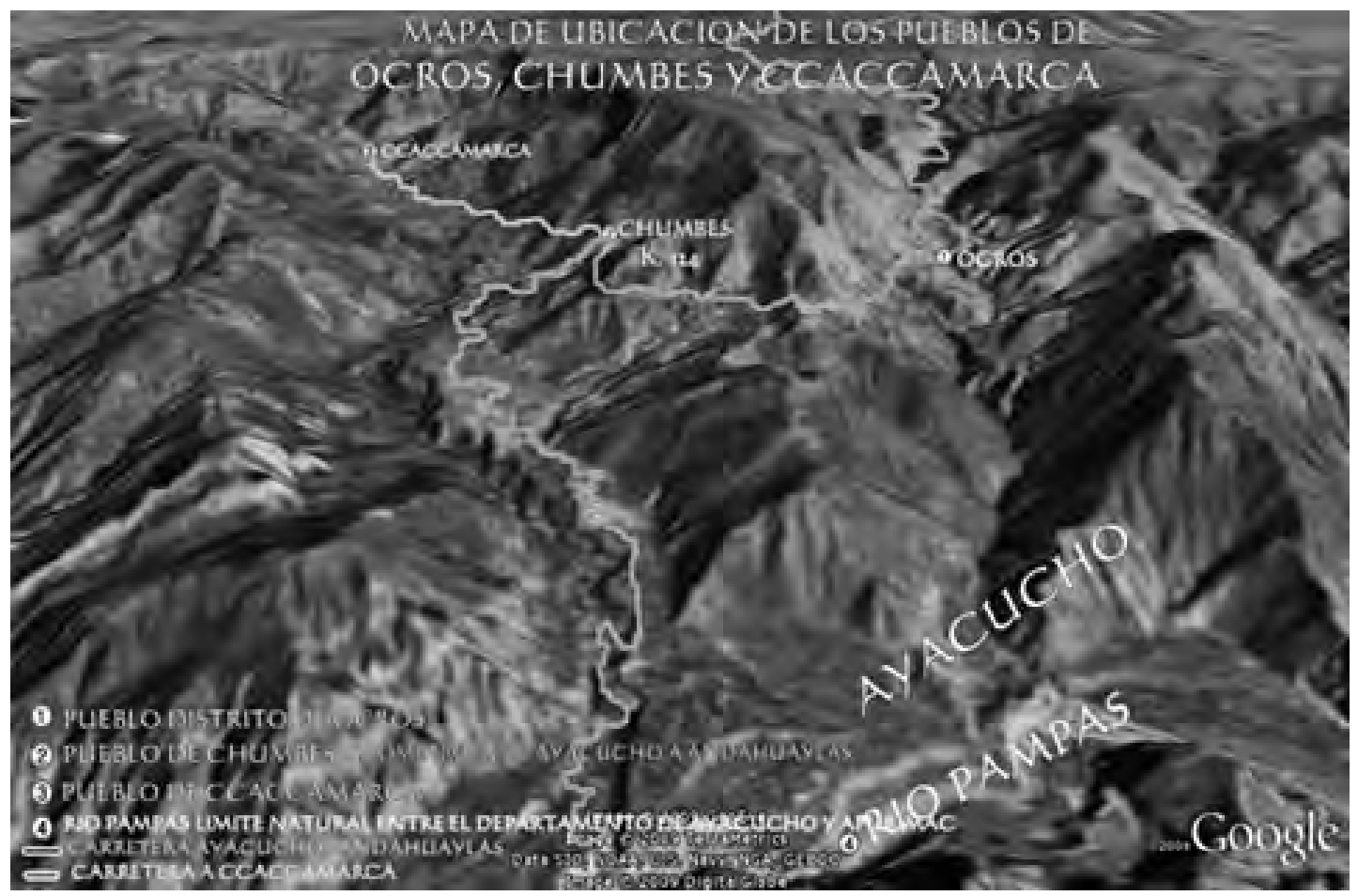

Figura 2: Vista panorámica de la microcuenca del río Qaqamarca. Fuente. Google Earth.

En este valle se percibe la presencia de mesetas, elevaciones, abismos, pendientes y pequeños riachuelos, además de una laguna (Angascocha) y ojos de agua que forman la fuente del río Qaqamarca (Figura 1 y 2); gracias a ello posee extensas áreas de cultivo donde se practica una agricultura intensiva, produciendo básicamente tubérculos y granos altoandinos (papa, quinua, cebada, habas, etc.); en las partes bajas el maíz (zea mays) y una gran variedad de frutales. Complementan esta actividad con la ganadería, la crianza de vacunos, ovinos y camélidos; y en la actualidad se advierte la presencia de piscigranjas (García 2009).

\section{METODOLOGÍA Y TÉCNICAS DE INVESTIGACIÓN}

Durante el trabajo de campo se empleó la prospección sistemática y de cobertura total, la cual era aplicable para nuestra zona, que consistió en localizar y documentar in situ las evidencias arquitectónicas y de cultura material visible a nivel de superficie; mediante recorrido a pie por zonas de fácil acceso a lo largo del valle. Los sitios hallados fueron georeferenciados y ubicados en la Carta Nacional 27-O de San Miguel.

Además, el reconocimiento incluyó la descripción de los sitios en una ficha de registro donde se describió el entorno medioambiental, las relaciones entre unidades arquitectónicas y los componentes espaciales inferidos a partir de las evidencias en superficie por medio del análisis intra-conjunto y del muestreo de tipo aleatorio simple. Seguidamente, se hizo el levantamiento planimétrico en base al croquis general de ubicación con la ayuda de jalones, cinta métrica, GPS y brújula, donde se detalla la descripción de formas y dimensiones. El registro incluyó la documentación gráfica y fotográfica de los asentamientos, estructuras funerarias, agrícolas y defensivas. 


\section{ANTECEDENTES DE ESTUDIO}

Son pocos los trabajos de índole arqueológico efectuados en el ámbito del distrito de Ocros y menos aún en la jurisdicción del valle de Chumbes. La información existente no es determinante para comprender el proceso de desarrollo de las poblaciones establecidas en los diferentes espacios físicos de este valle. Para tal fin, nos apoyamos con los resultados de investigaciones efectuadas en áreas adyacentes y cuyos datos nos facilitó correlacionar con el área de estudio.

En la segunda mitad del siglo XIX, viajeros extranjeros hacen referencia de las características geográficas de las áreas contiguas al camino de herradura o Qhapaq Ñan que recorre transversalmente por el ámbito del distrito de Ocros. En 1851 (1920) Clements R. Markham, en su recorrido de Ayacucho hacia Abancay divisó asentamientos prehispánicos y dio cuenta de la existencia de un puente colgante en las inmediaciones del río Pampas. El sabio Antonio Raimondi en 1858 (1942) atravesó estos parajes y describió la flora y aspectos geológicos de la zona; menciona también de la presencia del río Qaqamarca y el puente sobre el río Pampas: "Antes de llegar al río Pampas y a poca distancia, se pasa otro pequeño río que desagua en él. Se pasa sobre un bonito puente de cabulla, mejor construido que las anteriores y provisto de un torno para tenderlo con facilidad" (Ibíd. 1942: 112). En 1865 (1974) Ephraim G. Squier deja testimonio de su paso por el imponente río Pampas y detalla las características del puente colgante (Prehispánico - Colonial), además reporta algunos vestigios de antigua ocupación incaica asentados en los alrededores de esta zona. Y en 1880 (1993) Charles Wiener, informa sobre la existencia de haciendas instaladas en el valle de Chumbes como Occechipa, Asnacc, Majuelo, etc., todos de propiedad del hacendado José Parodi. Además hace una breve descripción del puente colgante situado sobre el río Pampas.

En 1942, el Dr. Julio C. Tello y su equipo de exploradores estuvieron de paso por la hacienda de Airabamba ubicada en la margen izquierda del río Pampas (Figura 4), hacen una somera descripción de la zona. En 1945/46, Pablo Carrera, Genaro Farfán y Marino González realizaron una excursión denominada Expedición arqueológica a la cuenca del rio Pampas, iniciando el recorrido desde Choclococha hasta la cuenca baja del río Pampas, arribaron a la hacienda de Ninabamba en el valle de Chumbes, donde aluden la existencia de andenerías en la zona. Posteriormente, Enrique González, Denise Pozzi-Escot y Cirilo Vivanco (1988), publican "El Área Histórica Chanka", en el que refieren elementos culturales e históricos que determinan el área territorial ocupada por los pueblos Chancas (Huancavelica-Ayacucho-Apurímac) y detallan la relación de un total de 348 sitios que se hallan a lo largo de la cuenca del río Pampas.

Otro aporte importante son los trabajos realizados por alumnos de la Universidad de Huamanga, quienes ejecutaron el catastro e inventario de sitios arqueológicos en áreas adyacentes del valle de Chumbes. Registrando con mayor frecuencia asentamientos de ocupación Chanca; en consenso llegan a explicar que los sitios de este periodo no solo se ubican en zonas de mayor elevación sino también en los valles, dominando un amplio horizonte rodeados de fortificaciones naturales y culturales. En 2001, Celestino Ochante en su trabajo "Prospección arqueológica en el Distrito de Concepción-Vilcashuamán", le permitió observar diversos sitios en su mayoría de procedencia Chanca asentados en los extremos y cima de los cerros de manera estratégica. Concluyendo que los grupos acantonados en esta jurisdicción fueron los que se resistieron a la conquista incaica y al ser derrotados cumplieron con la política de mitimaes. Unos años después, Rubén D. Espinoza (2003) en su trabajo de "Prospección arqueológica en la margen derecha del río Pampas en la jurisdicción de Rio Blanco, Ahuayro y Generosa", logra registrar 27 sitios arqueológicos ubicados en los diferentes pisos ecológicos y propone que los chancas se asentaron en la parte alta del Pampas predominando el patrón arquitectónico circular y aglutinado. 
El primer trabajo arqueológico en la zona fue realizado por Abel García (2009), en su informe titulado Reconocimiento arqueológico en la microcuenca del río Qaqamarca, valle de Ocros - Ayacucho, en base a evidencias culturales define una secuencia de larga ocupación ininterrumpida desde el periodo Formativo hasta el Horizonte Tardío. Sobre los Chancas dice que se asentaron en las partes altas, de patrón arquitectónico circular y aglutinado, con murallas y zanjas defensivas, asociados a la cerámica Tantaorqo, Qachisqo, Arjalla y Ayaorqo. Finalmente, Juan Bolívar (2010) en su informe "Ubicación y registro de restos arqueológicos en la margen derecha del río Qaqamarca, Ocros-Ayacucho", define una ocupación permanente desde la época Huarpa hasta el Intermedio Tardío. Registra un total de 05 sitios de filiación Chanca; concluyendo que fueron pequeñas aldeas rurales sin fortificaciones relevantes, asociados a espacios de entierros ubicados en pendientes adyacentes de cada uno de los sitios.
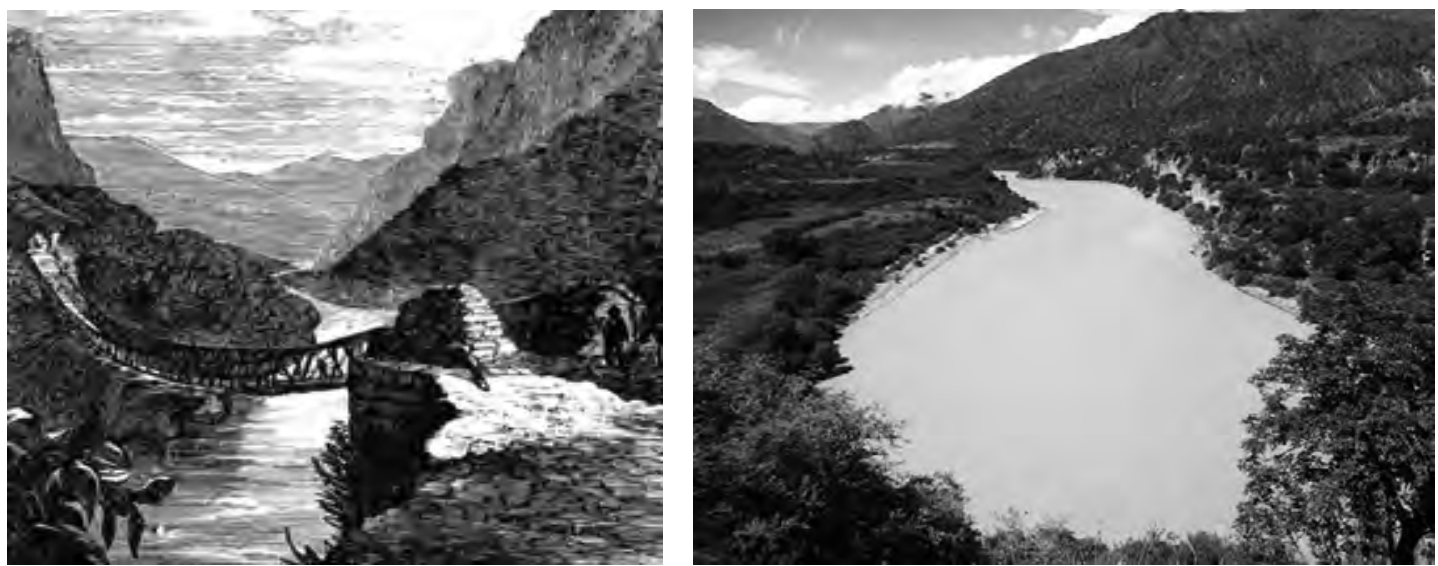

Figura 3-4: Puente sobre el río Pampas en un grabado de E. George Squier ([1865] 1974).

Derecha: El Valle bajo del Pampas, espacio donde se establecieron los aguerridos chancas.

\section{Sitios arqueológicos del Periodo Intermedio Tardío \\ en la Microcuenca del Río Qaqamarca - Valle de Chumbes}

Se registraron nueve asentamientos o llaqtas del Periodo Intermedio Tardío, situados sobre espacios abruptos e inaccesibles en ambas márgenes del río Qaqamarca.

\section{CUNCALLA}

Coordenadas UTM: 0612977 Este y 8513396 Norte. Altitud: 3, 339 m.s.n.m.

Ubicación: Se halla en la margen derecha del rio Qaqamarca y al norte de la comunidad de Ccaccamarca. Se llega al lugar tomando el camino de herradura de pendiente poco pronunciado que parte del poblado de Ccaccamarca y recorre por toda la cresta del cerro Cuncalla, Marayniyoq y Pizará. (Figura.5)

Se caracteriza por presentar un terreno de pendiente regular provista de vegetación dispersa. El suelo muestra poca profundidad, sobre la superficie se aprecia evidencias culturales tales como estructuras de planta circular y material cultural.

Descripción: En toda la cresta se advierte tres planicies de pendiente suave donde se aprecia algunos recintos aglutinados en mal estado de conservación, que por sus características lo definimos de función doméstica. Los recintos son de planta circular de 4.50 a $4.80 \mathrm{~m}$ de diámetro con muros de 0,40 
$\mathrm{m}$ de ancho y entre 0.20 a $0.30 \mathrm{~m}$ de alto; construidas de acuerdo al relieve del terreno, probablemente al inicio hubo más recintos, pero con el crecimiento demográfico y la expansión agrícola (moderna) muchas de estas estructuras fueron desmanteladas. En la falda del cerro se hallan gran cantidad de andenes en mal estado de conservación que van extendiéndose a lo largo de la pendiente, infraestructura agrícola construida como medida contra el efecto erosivo de las aguas y así aprovechar las laderas estériles. El riachuelo de Mañagua fue aprovechada mediante canales de irrigación, hoy en día en estos terrenos se practican la agricultura estacional y con riego.

De acuerdo a estas evidencias se puede decir que los pobladores de este lugar supieron manejar bien el medio geográfico en que les tocó vivir, donde los terrenos fueron utilizados para el cultivo y complementado con el pastoreo.

Estado de conservación: Malo, debido a factores naturales y antrópicos.

Tipo de sitio: Aldea con edificación doméstica.

\section{MAÑAGUA}

Coordenadas UTM: 0613689 Este y 8514826 Norte; Altitud: 3, 527 m.s.n.m.

Ubicación: El sitio se ubica sobre una planicie y a las faldas del cerro Mañagua, a $1 \mathrm{~km}$. de la comunidad de Ccaccamarca, en la margen derecha del río Qaqamarca. Se accede mediante un camino de herradura que parte del barrio Paqcha, ascendiendo por un camino empinado en dirección norte hasta la altura de Mañagua, de allí el camino es ligeramente llano hasta el sitio. (Figura 6)

La fuente de agua cercana son dos manantes ubicados en la falda del cerro Mañagua, cuyo cauce desemboca en el río Qaqamarca, en su recorrido va formando bofedales y se aprecia pastizales en toda la planicie. Presenta un terreno de suave inclinación, el suelo es profundo con rocas sueltas y dispersas. Sobre la superficie se hallan evidencias culturales dejadas por hombres que poblaron este sitio en la época prehispánica.

Descripción: El sitio está conformado por un área nuclear, donde se encuentran estructuras aglutinadas de planta circular en mal estado de conservación. Muestra poca evidencia en la distribución de los espacios, y algunas terrazas de función agrícola de poca visibilidad, las estructuras de las viviendas están distribuidas en forma desordenada sobre la planicie y ladera. Construidas en terrenos previamente preparados, aun son visibles los pisos planos y algunos muros de contención. Con diámetros de 3 a $6 \mathrm{~m}$ y alturas de 0.10 a $0.15 \mathrm{~m}$, con muros de $0.40 \mathrm{~m}$ elaboradas con piedras de campo unidos con argamasa; no se identificaron recintos cuadrangulares ni rectangulares solo espacios abiertos. Además se observa tres espacios pequeños o "pucullos" de 1 a $1.50 \mathrm{~m}$ de diámetro con muros de $0.30 \mathrm{~m}$ de ancho.

Mañagua fue un poblado que tuvo un proceso de ocupación particular, aprovecharon los territorios aledaños de Paqcha, Lucre, Cuculipunco, etc. para la producción agrícola y ganadera. Por la cercanía habría mantenido una relación estrecha con el sitio de Cuncalla, la distribución del espacio muestra una ocupación planificada ligada a áreas productivas y defensivas.

Estado de conservación: Malo, debido a factores naturales y antrópicos.

Tipo de sitio: Aldea con edificación doméstica. 

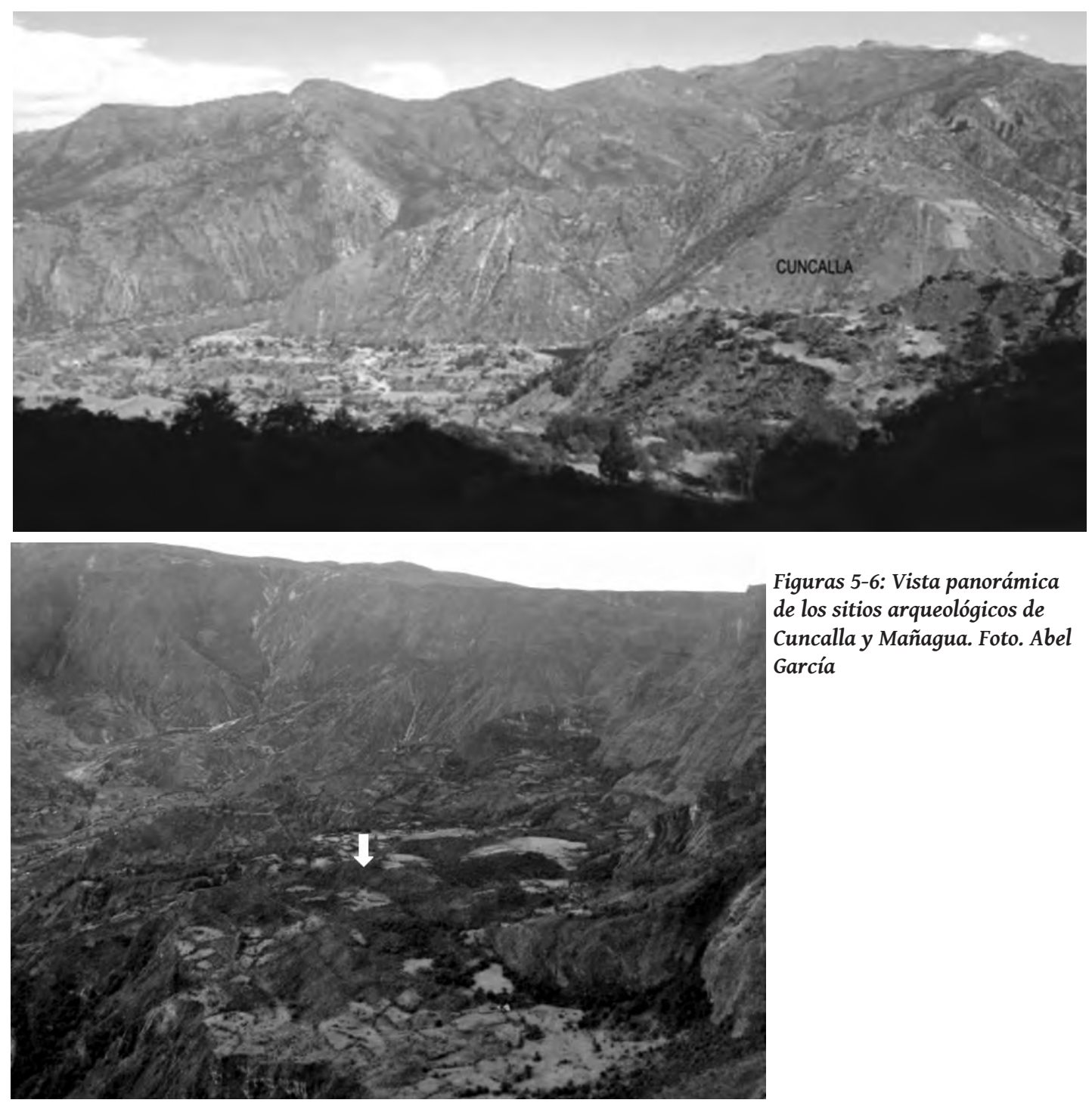

Figuras 5-6: Vista panorámica de los sitios arqueológicos de Cuncalla y Mañagua. Foto. Abel García

\section{HUAYNA PIZARRO}

Coordenadas UTM: 0616034 Este y 8516802 Norte; Altitud: 3, 912 m.s.n.m.

Ubicación: Se sitúa a lo largo de la cresta del cerro Huayna Pizarro, al oeste de la comunidad de Santa Isabel de Chumbes. Se llega al lugar tomado el camino de herradura que va hacia Pumaqahuanqa y la ciudad de Ayacucho; de la planicie San Pedro se toma un desvío en dirección suroeste donde el camino es llano hasta el sitio.

El sitio se define por la presencia de algunos recintos domésticos y corrales ganaderos emplazados sobre la cresta del cerro, las mismas que están asociadas a un ushnu de doble plataforma en mal estado de conservación. En la parte inferior y adosado al afloramiento rocoso se construyeron las estructuras funerarias con entierros múltiples profanados. Para mejor entendimiento se describe cada una de las cuatro estructuras mortuorias resaltantes. 
Estructura funeraria № 01: Se trata de una cámara funeraria parcialmente destruida, adosada a la pared vertical de un acantilado, para lo cual aprovecharon un pequeño abrigo rocoso. Están hechas con piedras de campo y unidas con barro, de $2.0 \mathrm{~m}$ de diámetro y $0.80 \mathrm{~m}$ de alto por $0.60 \mathrm{~m}$. de ancho, la pared externa e interna se inclinan ligeramente hacia el interior. El aparejo es simple ya que las piedras están colocadas en caras planas, sin ningún tipo de enlucido, no se pudo ubicar el acceso. Asociada a esta estructura se halló restos óseos completamente destruidos y dispersos en la superficie, posiblemente haya obedecido a un entierro múltiple. (Figura.7)

Estructura funeraria № 02: Se trata de una pequeña cámara funeraria ubicado a $30 \mathrm{~m}$ al norte de la estructura № 1. Para la construcción aprovecharon un pequeño abrigo que está al pie del acantilado, se trata de una construcción simple, donde las piedras están unidas sin argamasa de barro. Su condición de lajas facilita que la pared interna presente un aparejo regular debido a que están colocadas en caras planas. La estructura funeraria tiene la forma de "D" de $1.70 \mathrm{~m}$ de diámetro por $0.70 \mathrm{~m}$ de espesor y la altura variable, los muros muestran diferencia marcada en ambas caras y ambas paredes se inclinan hacia el interior. Los escombros dificultaron la ubicación del acceso.

Estructura funeraria № 03: Se trata de una cámara funeraria bastante destruida, ubicado al pie del acantilado que forma un abrigo rocoso poco profundo que previamente fue utilizado como cantera de extracción de andesita. Cimentada con lajas de andesita y unidos con barro, el espesor de muro es de $0.80 \mathrm{~m}$; la planta interior es semicircular en forma de "D" cuyo diámetro oscilan entre 1.0 a 2.0 $\mathrm{m}$. La pared interna y externa se inclinan ligeramente hacia el interior, el aparejo interno es regular. Al interior se observan restos óseos desarticulados y algunos cráneos con deformación fronto occipital oblicuo y fracturas de golpe contundente. (Figura.8)

Estructura funeraria № 04: Ubicado a pocos metros al norte de la cámara № 03, para su construcción aprovecharon la pendiente del acantilado. Se trata de una cámara funeraria construida con piedras de campo y unidos con barro, de $0.60 \mathrm{~m}$ de espesor, la planta interna tiene la forma de "D" y el diámetro es de $2.0 \mathrm{~m}$ por $1.70 \mathrm{~m}$ de ancho y una altura de $0.70 \mathrm{~m}$. Posiblemente haya tenido un techo en forma de falsa bóveda, al interior se hallan restos óseos como cráneos y extremidades desarticuladas dispersos sobre la superficie, obedeciendo a un entierro colectivo.

Estado de conservación: Malo, debido a factores naturales y antrópicos.

Tipo de sitio: Sitio funerario.

\section{BALCóN}

Coordenadas UTM: 0616830 Este y 8517532 Norte; Altitud: 3, 858 m.s.n.m.

Ubicación: El sitio se ubica sobre una planicie semiaccidentada al norte de la comunidad de Chumbes y a la margen derecha del río Qaqamarca. Se llega al lugar tomando el antiguo camino de herradura que se dirige de Chumbes hacia Ayacucho, en la cima del cerro Balcón y a escasos metros del camino se sitúa el sitio epónimo.

Descripción: Balcón, se define como un conjunto de recintos emplazados de forma irregular, de clara función doméstica y pastoril. En la cima del sitio se encuentran recintos de planta circular, pero estos, a diferencia de los ubicados en la parte baja, presentan diámetros que varían de 5,0 a 12,0 m, y alturas de 0.50 a $0.80 \mathrm{~m}$, los muros tienen un ancho de 0.30 a $0.40 \mathrm{~m}$. Además se distingue tres corrales de planta circular de 18 a $20 \mathrm{~m}$ de diámetro y $1.20 \mathrm{~m}$ de espesor de muro (Figura.10). Estas estructuras presentan una conformación de doble hilera como técnica constructiva y están asociados a un camino prehispánico. Lo conforman dentro de los límites naturales, algunas terrazas agrícolas en estado de 

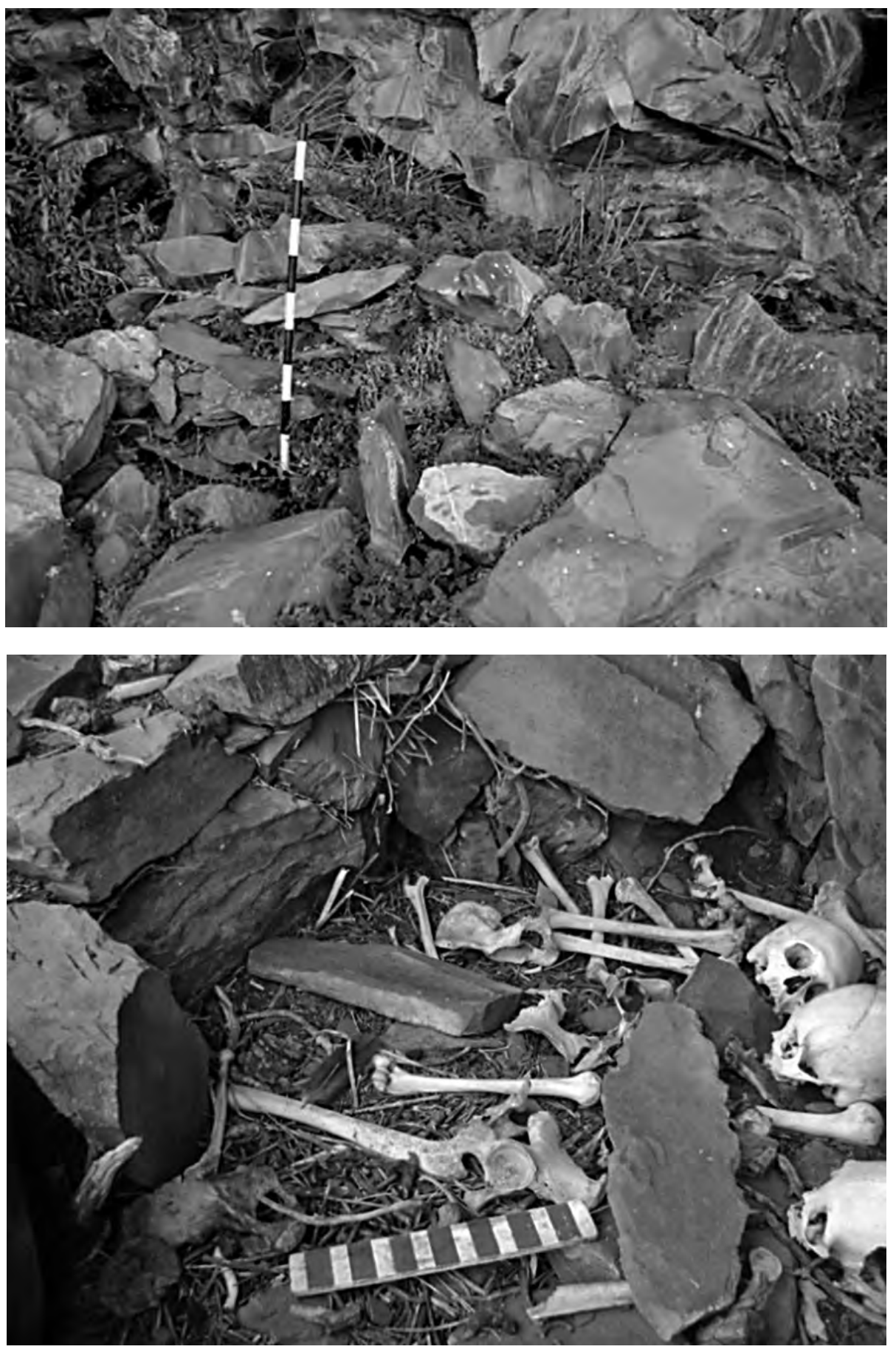

Figura 7-8: Arriba, vista del acceso tapiado de la estructura funeraria № 01. Abajo, restos óseos dispersos. 
destrucción, con algunos espacios abiertos en forma de media luna, muchos de ellos han sido removidas por los pastores para la construcción de corrales.

Estructuras funerarias: Hacia el sur, en una zona completamente empinada e inaccesible se hallan entierros colectivos bastante profanados, todas ubicadas entre grietas rocosas y divididas mediante grandes rocas que cubren los entierros acorde a su elevación. En la cima de esta colina afloran los cimientos de dos chullpas (figura 9) bastante destruidas y con signos de haber sido huaqueadas, por el mal estado en la que se encuentran no se pudo apreciar las características de los muros. En la superficie se halló material cultural como fragmentos de cerámica de clara filiación Chanca y artefactos líticos, elaborados con el mismo material pétreo de las estructuras.

Balcón fue una pequeña aldea que mantuvo una estrecha relación con el sitio arqueológico de Llaqtapata, este último fue un poblado de gran importancia en la zona, siendo Balcón un espacio utilizado para la producción agrícola y de pastoreo.

Estado de conservación: Malo, debido a factores naturales y antrópicos.

Tipo de sitio: Aldea con edificación doméstica y pastoril.

\section{LLAQTAPATA}

Coordenadas UTM: 06183376 Este y 8517340 Norte; Altitud: 3, 594 m.s.n.m.

Ubicación: Se ubica en la margen izquierda de la microcuenca del río Qaqamarca y la margen izquierda de la cuenca baja del río Pampas, en la cima del cerro epónimo. La vía de acceso al sitio se realiza mediante un camino de herradura de pendiente bastante pronunciada que parte del centro poblado de Chumbes. El camino se inicia con rumbo en dirección norte cuesta arriba, por una senda zigzagueante hasta el abra de Tastapata, luego cambia de rumbo en dirección este con una pendiente llana hasta arribar al sitio.

Descripción: Es un conjunto habitacional de forma irregular que se halla sobre una planicie en la parte alta del cerro epónimo. Se trata de una colina de suave pendiente, en donde se hallan restos de viviendas de planta circular en mal estado de conservación. Sobre muros de contención que forman terrazas, es decir, que el terreno ha sido acondicionado para obtener un piso plano. En este sector se han identificado alrededor de 30 unidades arquitectónicas en disposición dispersa y aglutinada, las cuales constan de las bases de estructuras de planta circular cuyos diámetros varían de 4,0 a 5,0 m. Estas estructuras presentan un solo vano de acceso de $0.80 \mathrm{~m}$ de ancho x $1.0 \mathrm{~m}$ de alto, los cuales no presentan una uniformidad en su orientación; además los muros que la conforman tienen anchos que varían entre los 0.40 y $0.60 \mathrm{~m}$ con una ligera inclinación hacia el interior de los recintos. Las paredes son de doble hilada, puestas horizontalmente con piedras largas superpuestas una sobre otra y entre las uniones se aprecia pachillas, el aparejo es ordinario (figura 11-12)

Sistemas defensivos de murallas y zanjas: La ubicación del sitio es estratégico, ya que está circundado por un precipicio de gran altura lo que le hace casi inaccesible. El sitio está protegido por un sistema de zanjas y murallas, las zanjas se orientan de sur a norte con dimensiones de $11 \mathrm{~m}$ de largo por $2.0 \mathrm{~m}$ de ancho. Aprovecharon la pendiente para construir tres murallas de defensa, la primera muralla mide $5.0 \mathrm{~m}$ de largo x $1.30 \mathrm{~m}$ de ancho y $1.50 \mathrm{~m}$ de altura. La segunda muralla mide $17 \mathrm{~m}$ de largo x $1.64 \mathrm{~m}$ de ancho y $1.45 \mathrm{~m}$ de altura. La tercera muralla mide $10 \mathrm{~m}$ de largo x $1.22 \mathrm{~m}$ de ancho y $1.90 \mathrm{~m}$ de altura. Para su construcción utilizaron piedras grandes y medianas de acuerdo a la topografía del terreno. Estructuras defensivas que servían para impedir el acceso al centro urbano y así contrarrestar los ataques de grupos enemigos. En toda la superficie se registró una gran cantidad de material cultural como fragmentos de cerámica de filiación Chanca y artefactos líticos. 

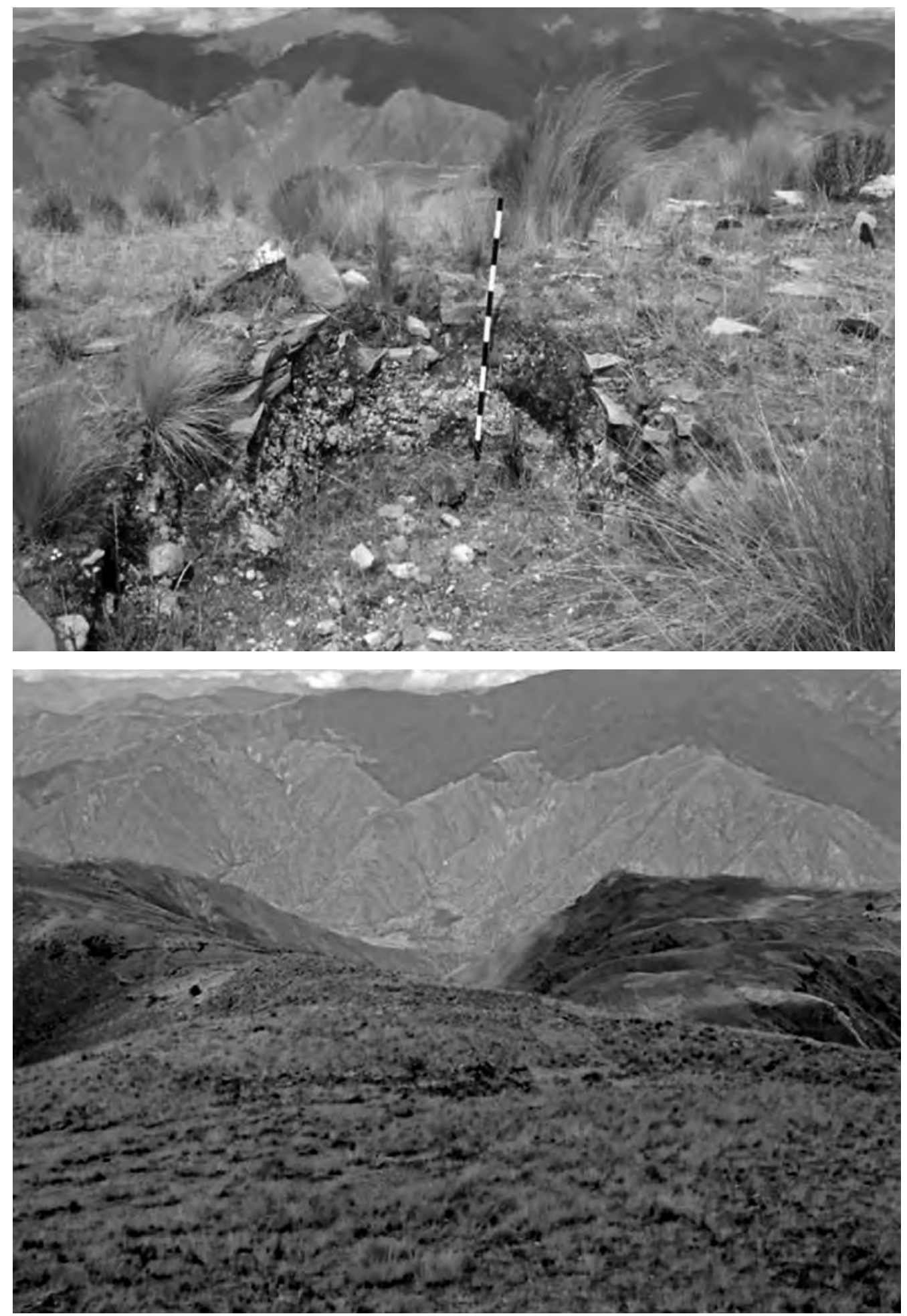

Figura 9 (Arriba): Vista de la base de una chullpa disturbada. Figura 10 (Abajo) vista de un corral en Balcón. 


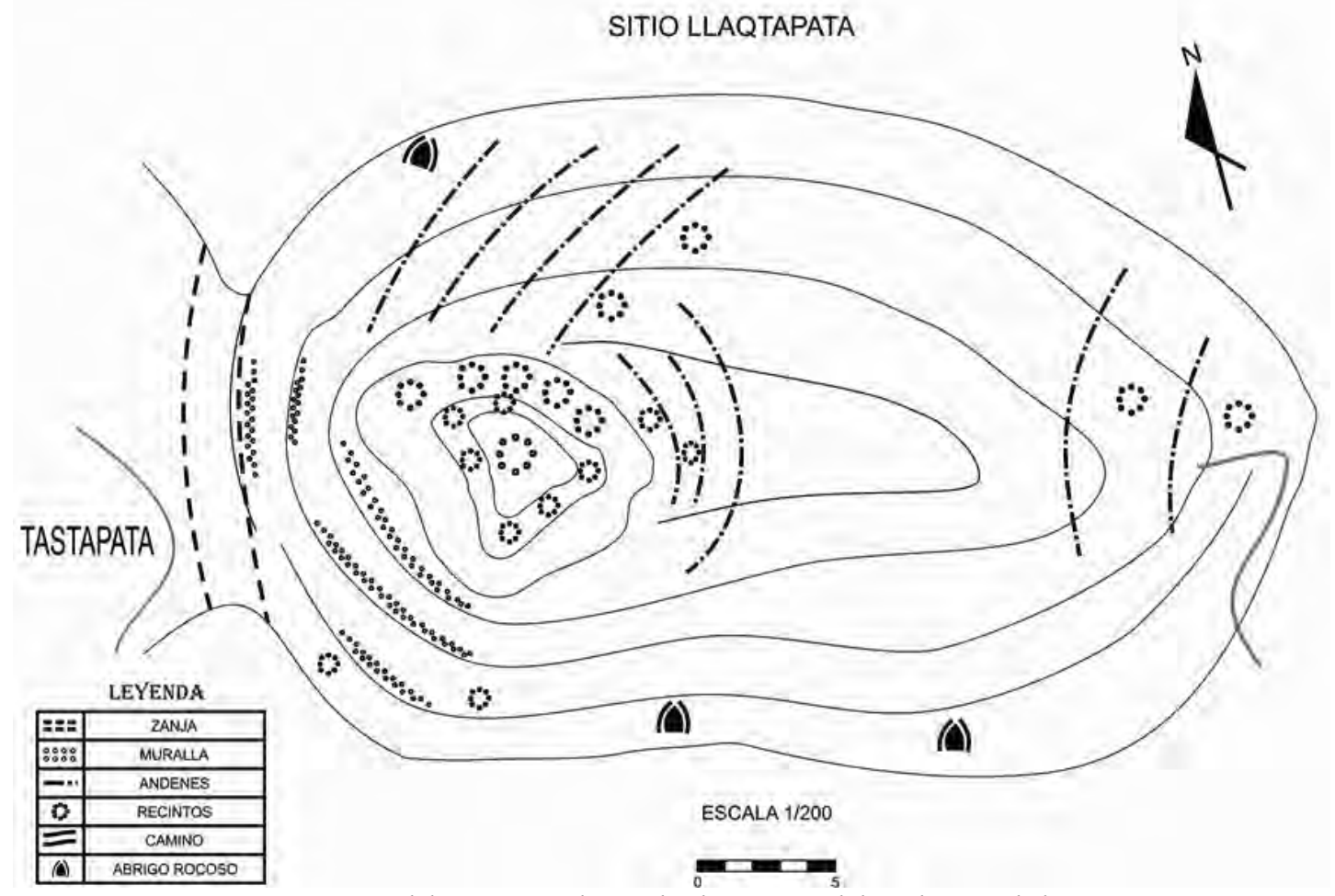

Figura 11: Croquis del sitio arqueológico de Llaqtapata. Elaborado por. Abel García R.

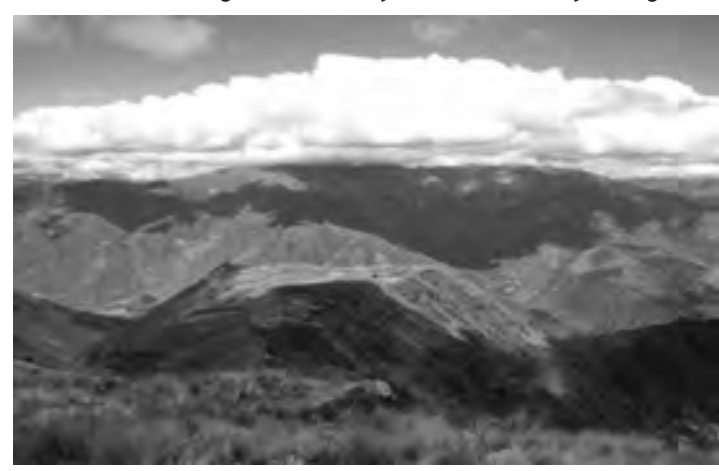

Figura 12: Vista panorámica del sitio Llaqtapata.

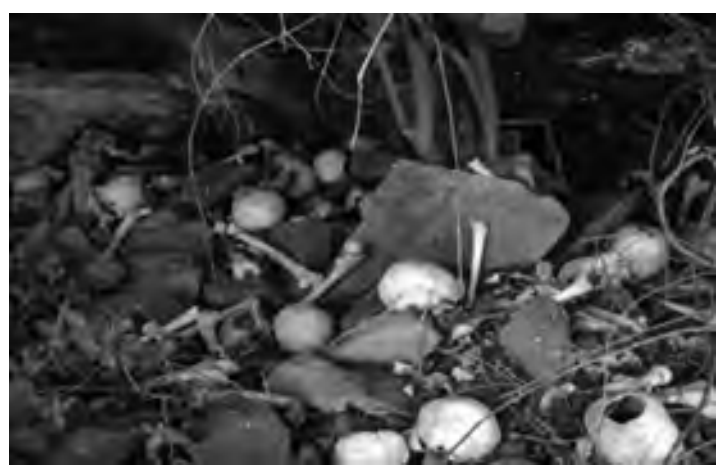

Figura 13: Restos óseos en un abrigo rocoso.

Estructuras funerarias: En una zona completamente empinada e inaccesible se hallaron un conjunto de abrigos rocosos debajo de enormes rocas desprendidas de 4.5 a $6.0 \mathrm{~m}$ de altura x 5.0 a $8.0 \mathrm{~m}$ de ancho y con 0.80 a $2.0 \mathrm{~m}$ de profundidad, en cuyo espacio interno se registró un conjunto de osamentas disgregadas bastante profanadas. (Figura 13) Además se perciben cráneos con deformación oblicua frontoccipital tubular, que revelan signos de fractura antemorten producto de golpes contundentes y algunos de ellos con signos de regeneración.

Estado de conservación: En general los recintos domésticos y defensivos se conservan en mal estado. Las estructuras funerarias presentan evidencias de profanación.

Tipo de sitio: Poblado fortificado con edificación doméstica. 


\section{VENTANAYOQ}

Coordenadas UTM: 0619057 Este y 8516128 Norte; Altitud: 3, 317 m.s.n.m.

Ubicación: Se localiza sobre un terreno accidentado en la margen izquierda del río Qaqamarca y la cuenca baja del río Pampas. Se llega al lugar siguiendo el camino de herradura que va de la comunidad de Chumbes hacia el cerro Llaqtapata, y a la altura del paraje de Allpaorqona cambia de rumbo en dirección este siguiendo la cresta del cerro hasta arribar al sitio epónimo.

Descripción: Presenta un terreno de pendiente accidentado, el suelo es rocoso de poca profundidad y la tierra arcillosa de color negro. Para realizar un mejor registro de campo, el asentamiento fue sectorizado en dos áreas de acuerdo a sus características topográficas, variabilidad de las estructuras arquitectónicas y densidad del material cultural asociado. Estos sectores han sido denominados: V-1 y V-2. (Figura 14)

Sector A (V1)2: Se encuentra ubicado en la parte más elevada del promontorio natural y está constituido por la mayor cantidad de estructuras arquitectónicas y densidad de material cultural en superficie. En este sector existe mayor concentración de viviendas de planta circular, edificadas sobre terrazas artificiales debido a lo accidentado de la topografía de este sector. Las estructuras presentan diámetros que varían de 3.0 a $6.0 \mathrm{~m} \times 0.40$ a $0.50 \mathrm{~m}$ de ancho y una altura de 0.50 a $1.50 \mathrm{~m}$, con algunos patios y separaciones individuales acomodadas de acuerdo al medio geográfico, no tienen calles ni otros espacios importantes que pudieron servir para realizar alguna ceremonia o reunión. Las estructuras están hechas con piedras naturales del lugar, unidos con argamasa de barro y distribuidas de forma desordenada, en otros casos han excavado la tierra para acondicionar los muros, a veces un solo muro delimita dos viviendas. Sobre los espacios elevados del cerro se registraron cuatro recintos circulares, ubicados de manera estratégica de 3.0 a $4.0 \mathrm{~m}$ de diámetro, decretados como puestos de vigilancia.

Sector B (V2) ${ }^{3}$ : En este sector se han identificado alrededor de 50 unidades arquitectónicas, las cuales constan de estructuras de planta circular cuyos diámetros varían de $4.5 \mathrm{~m}$. Estas estructuras presentan un solo vano de acceso de $0.60 \mathrm{~m}$ de ancho x $1.20 \mathrm{~m}$ de alto, los cuales no presentan una uniformidad en su orientación. La altura promedio de estas estructuras es de $1.10 \mathrm{~m}$, además los muros que la conforman tienen anchos que varían entre los 0.40 y $0.60 \mathrm{~m}$ con una ligera inclinación hacia el interior de los recintos. El material constructivo utilizado para la edificación del asentamiento es principalmente local, utilizando piedras de canteado rustico sin labrar, estos fueron unidos con una argamasa elaborada a base de barro. (Figura 15-16)

Sistemas defensivos (zanjas): Presenta cinco zanjas que van cortando la cresta del cerro. La primera mide $1.10 \mathrm{~m}$ de ancho y $2.0 \mathrm{~m}$ de profundidad. La segunda mide $3.0 \mathrm{~m}$ de ancho x $2.0 \mathrm{~m}$ de profundidad. La tercera mide $2.0 \mathrm{~m}$ de ancho $\times 1.80 \mathrm{~m}$ de profundidad. $Y$ la cuarta, la más grande, mide entre 7.0 a $8.0 \mathrm{~m}$ de ancho x $4.0 \mathrm{~m}$ de altura. Finalmente, la quinta zanja mide $5.0 \mathrm{~m}$ de ancho $\times 1.20 \mathrm{~m}$ de altura. Estas evidencias indican que este sitio estuvo protegido por un sistema de zanjas y muros que tenían la función de impedir el acceso de grupos enemigos al centro de las viviendas.

Andenes: Se ubican hacia el lado oriental en los sitios denominados Siqsiynuyoqcucho, Tinajería, Qatunhuayqo y Chumbes. Tienen formas y tamaños muy variados, y fueron elaborados de manera rústica; constituyeron una de las medidas contra el efecto erosivo de las aguas y así aprovechar las laderas estériles para generar una actividad agrícola.

Estructuras funerarias: En áreas completamente empinadas e inaccesibles se hallaron entierros colectivos e individuales profanados, debajo de enormes rocas que forman abrigos en donde se divisa restos óseos humanos disturbados y dispersos. En algunos abrigos aún persisten cimientos de posibles cámaras funerarias, que debieron haber tenido un sistema de edificaciones con divisiones internas mediante muros de mampostería. Encontramos dos tipos de construcciones fúnebres: 


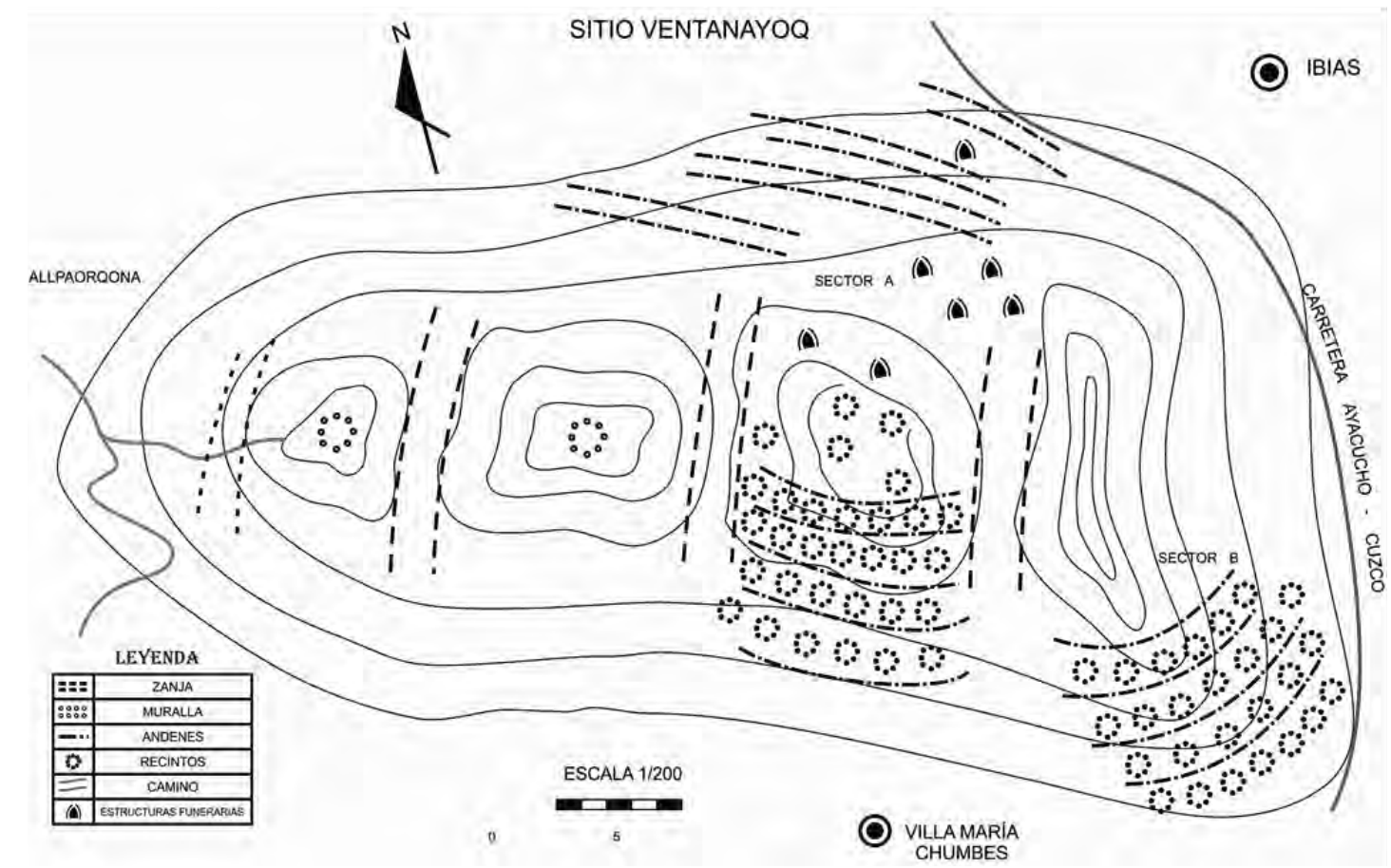

Figura 14. Croquis general del sitio arqueológico Ventanayoq.
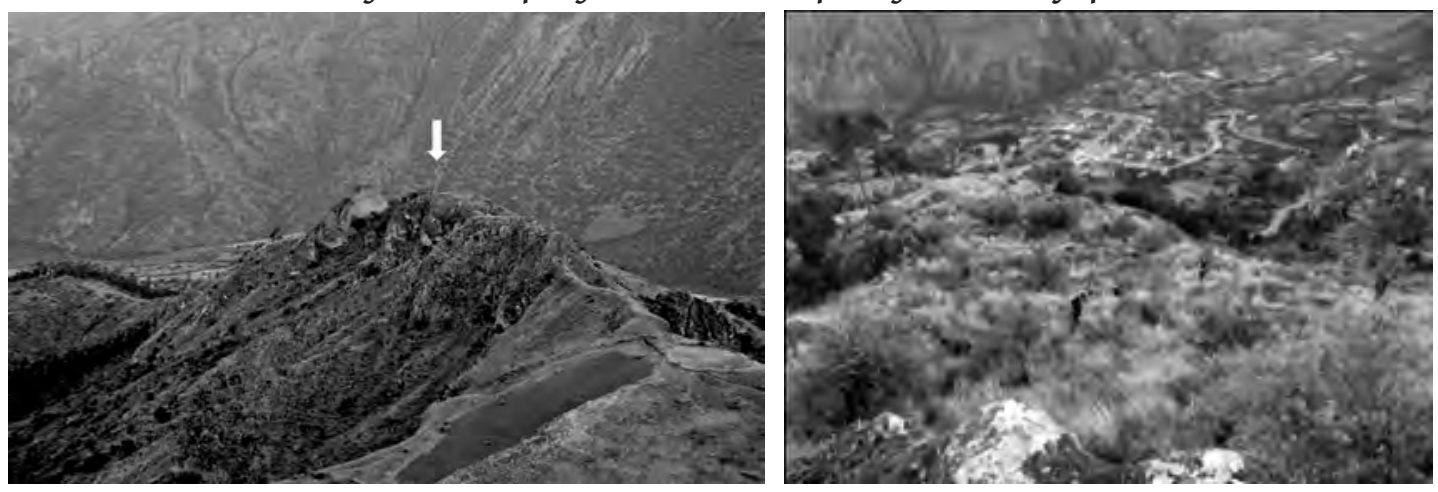

Figura 15-16: Vista general de los Sectores A y B del sitio arqueológico Ventanayoq

Estructura Funeraria № 01. Se ubica debajo de una enorme roca de $6.0 \mathrm{~m}$ de alto, cuya base ha sido aprovechada para la construcción de una cámara funeraria de forma cuadrangular adosada a la pared, cimentadas con piedras de campo y unidas con argamasa de barro. El acabado de sus muros es de aparejo simple, cuyas dimensiones son de $1.50 \mathrm{~m}$ de largo x 1.30 $\mathrm{m}$ de ancho, $0.80 \mathrm{~m}$ de espesor y la altura es de $0.80 \mathrm{~m}$. Se halla poca cantidad de restos óseos humanos dispersos, asociados a algunos fragmentos de cerámica de clara filiación Wari que formó parte del ajuar funerario.

Estructura Funeraria № 02 . Ubicado hacia el lado sur del sitio, enclavado bajo una gran roca en la cual se construyó una cámara funeraria, elaborada con piedras de campo y unidos con barro. La estructura está adosada a la pared de una roca de $4.0 \mathrm{~m}$ de alto x $3.0 \mathrm{~m}$ de ancho, tiene una forma circular de $2.10 \mathrm{~m}$ de diámetro por $1.20 \mathrm{~m}$. de alto; la abertura del abrigo tiene 
$1.80 \mathrm{~m}$ de profundidad y la pared se inclina ligeramente hacia el interior. En el espacio interno se observan restos óseos disturbados.

Estado de conservación: en general los recintos domésticos y defensivas se conservan en mal estado. Las estructuras funerarias presentan evidencias de profanación.

Tipo de sitio: Centro Poblado fortificado con edificación doméstica.

\section{LLAQTAPATA II}

Coordenadas UTM: 0621792 Este y 8516952 Norte, Altitud: 3, 020 m.s.n.m.

Ubicación: Se ubica en la margen izquierda de la microcuenca del río Qaqamarca y al noreste del poblado de Ibias. Se llega al lugar siguiendo la trocha carrozable que sale del poblado de Ibias en dirección noreste hasta una pequeña quebrada que colinda con el camino Qhapaq Ñan (tramo Ayacucho-Chincheros), de allí tomar el camino de herradura hasta llegar a la cima del cerro epónimo donde se halla el sitio arqueológico.

El cerro tiene una forma tronco cónica de topografía accidentada con declives inaccesibles, está provistos de rocas medianas y cubiertos de vegetación. El suelo presenta poca profundidad debido a la presencia de rocas y cascajo en el subsuelo, la tierra es arcillosa de color negro.

Descripción: El sitio se define por la presencia de un conjunto de recintos domésticos emplazados sobre la cima del cerro Llaqtapata. Y sobre este cerro aparecen concentrados y aglutinados un conjunto de recintos de planta circular, que por sus características los definimos de función doméstica. Recintos de planta circular de 3.0 a $6.0 \mathrm{~m}$ de diámetro y 0.80 a $0.90 \mathrm{~m}$ de altura, el espesor de muro de 0.50 a $0.60 \mathrm{~m}$. los muros están construidos con piedras de campo y unidos con barro, el aparejo es ordinario. Los recintos están edificados en terrenos previamente preparados, es decir para tener un piso plano han construido muros de contención, muchos de ellos adosados unos a otros y en algunos casos un solo muro delimita a dos viviendas. Asociado a las estructuras circulares se registró el cimiento de un recinto de forma cuadrangular de $2.50 \mathrm{~m}$ de largo x $2.0 \mathrm{~m}$ y $0.60 \mathrm{~m}$ de espesor de los muros. En la superficie se registró fragmentos de cerámica de filiación Chanca. (Figura 17)

Andenes: Hay un conjunto de andenes agrícolas de forma y tamaño diverso que descienden sobre la ladera del cerro; sus muros fueron construidos de manera rústica. Actualmente están abandonados y cubiertos por la vegetación.

Camino: Se observa un camino prehispánico o Qhapaq Ñan que cruza transversalmente por el valle de Chumbes, y hacia las faldas del cerro Llaqtapata el camino asciende por la pendiente hasta el sitio. Los bordes del camino están cercados con muros a modo de parapetos y escalinatas pequeñas cerca al cerro. (Figura 18)

Estado de conservación: Malo, en general los recintos domésticos y agrícolas se conservan en mal estado.

Tipo de sitio: Poblado aldeano con edificación doméstica y agrícola.

\section{VACA VELANA}

Coordenadas UTM: 0616807 Este y 8514318 Norte; Altitud: 2,771 m.s.n.m.

Ubicación: Ubicado sobre una planicie relativamente llana al suroeste de la comunidad de San José la Colpa en la margen derecha del río Qaqamarca. Se llega al lugar tomando el camino de herradura que se dirige de la comunidad de San José La Colpa hacia la estancia de Quispepampa, de allí se toma un desvío hacia el oeste hasta arribar al sitio. El sitio presenta una topografía suave. En toda la 
Anuor García / Arqueología del distrito de Ocros: asentamientos del periodo intermedio tardío

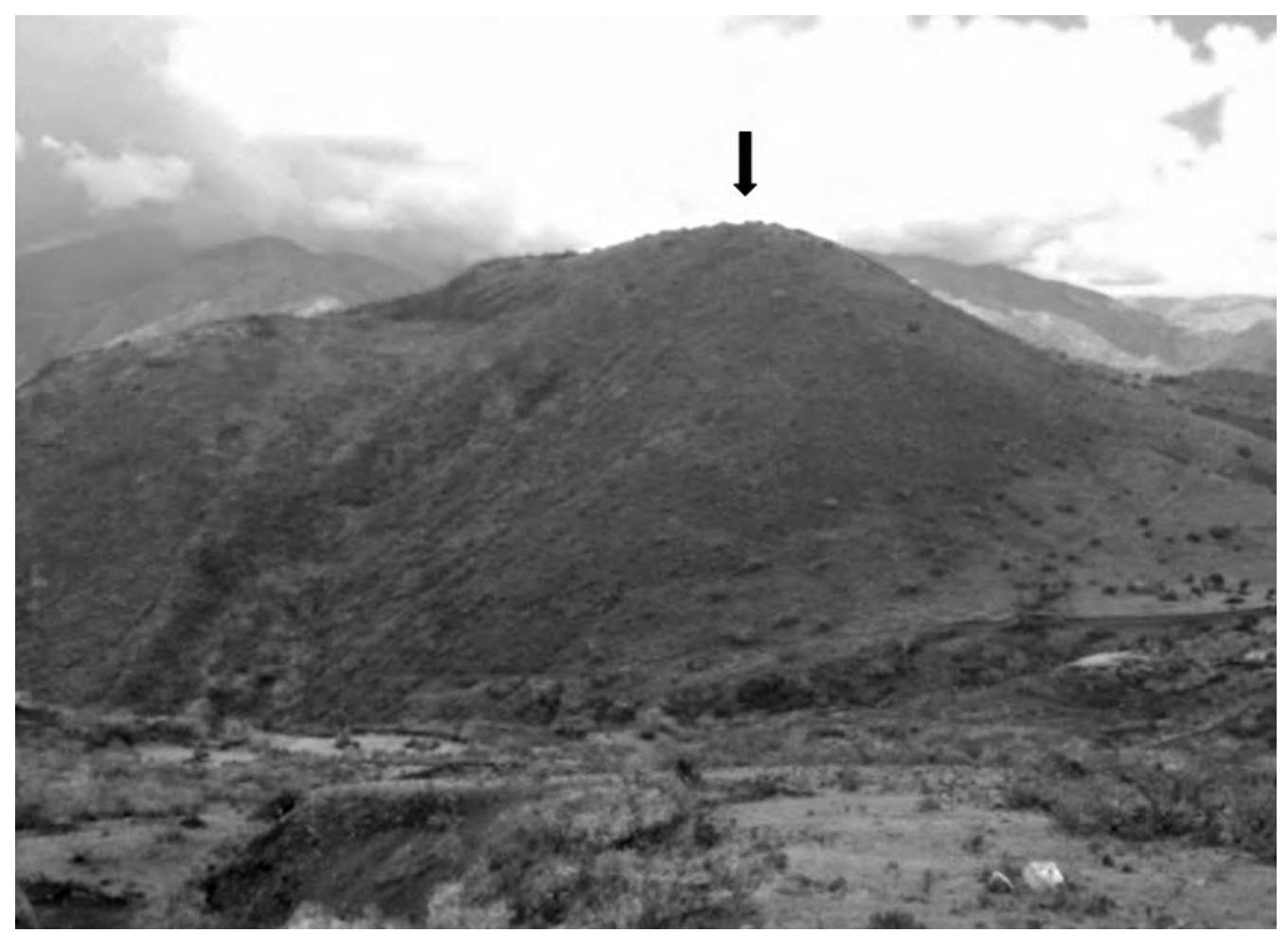

Figura 17: Vista panorámica del sitio Llaqtapata II.

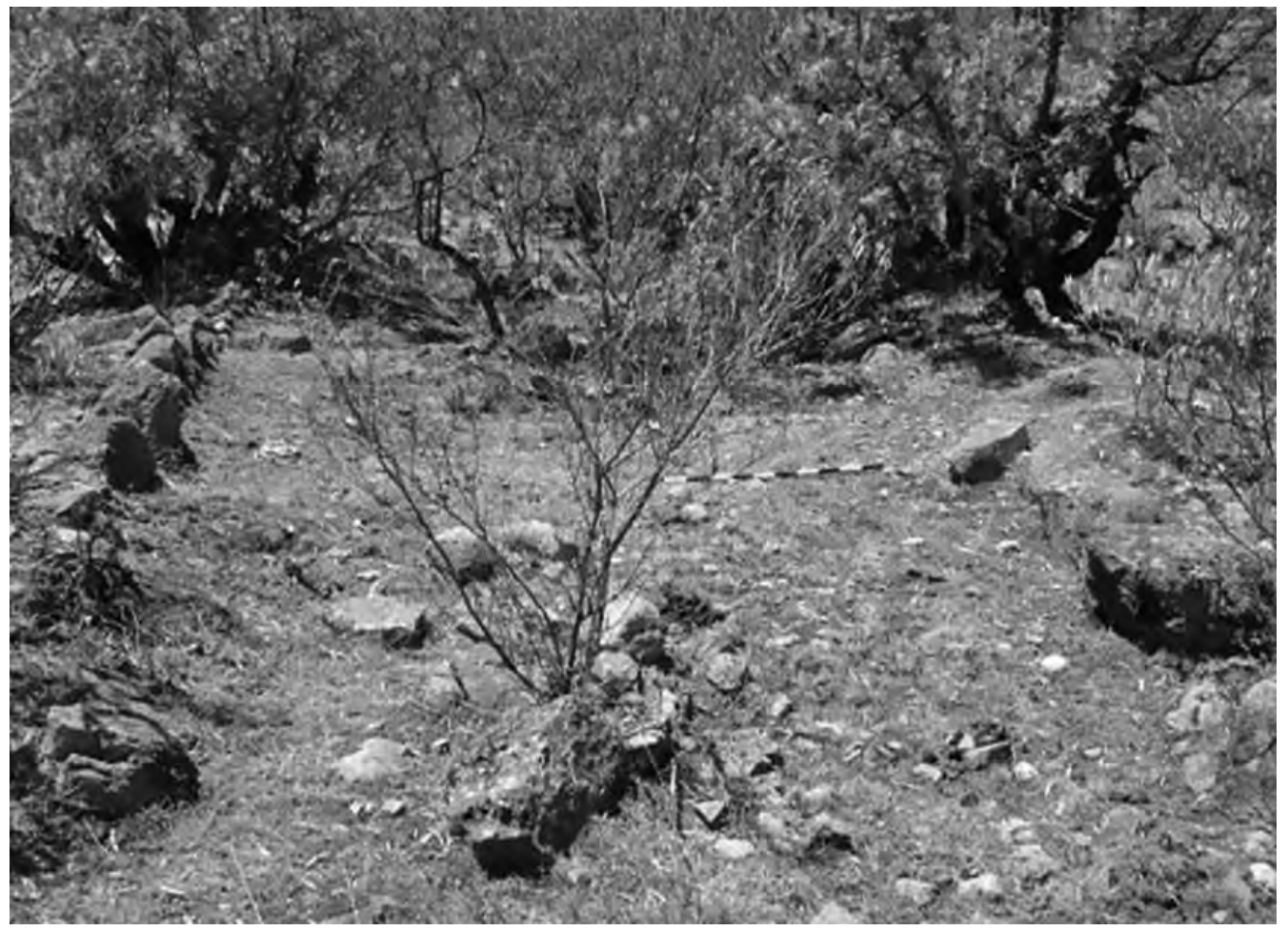

Figura 18: Segmento de camino que accede al sitio. 
franja sur se halla un acantilado de unos $70 \mathrm{~m}$. de altura, el suelo es profundo y propicio para la producción agrícola.

Descripción: El sitio está ubicado en una planicie de ligera inclinación y se define por la presencia de un conjunto de recintos concentrados y aglutinados, que por sus características lo definimos de función doméstica. Recintos de planta circular hechas a base de piedras y unidos con barro, el aparejo es ordinario puesto que las piedras son de distintos tamaños. El conjunto de viviendas exponen diámetros de 5.0 a $7.0 \mathrm{~m} \mathrm{x} 0.60-0.70 \mathrm{~cm}$ de espesor de muro, los vanos de acceso son angostos y no miden más de $0,80 \mathrm{~m}$, la altura es de 0.70 a $1.0 \mathrm{~m}$. Se trata de un patrón constructivo organizado que se disponen alrededor de los espacios abiertos. También registramos recintos cuadrangulares y rectangulares de $10 \mathrm{~m}$ de largo x $8.0 \mathrm{~m}$ de ancho y $0.40 \mathrm{~m}$ de alto y $1.0 \mathrm{~m}$ de espesor de muro; espacio que estuvo destinada a la administración. (Figura 19-20)

La muralla: Está representado por la base de un muro de $1.0 \mathrm{~m}$ de ancho x $0.20 \mathrm{~m}$ de alto, con una longitud superior a las $20 \mathrm{~m}$ que circunda todo el asentamiento.

Las zanjas: El sitio está cercado por una gran zanja de $400 \mathrm{~m}$ de largo x $10 \mathrm{~m}$ de ancho $2.0 \mathrm{~m}$ y de profundidad actual, reforzado con piedras para evitar el derrumbe. Esta evidencia indica que servían para impedir el acceso de los grupos enemigos.

Los andenes: A los alrededores hay un conjunto de andenes que se expande por todo el área, con dimensiones de 10 a $15 \mathrm{~m}$ de largo x 2 a $8 \mathrm{~m}$ de ancho. En la superficie se registró material cultural, como fragmentos de cerámica Chanca y artefactos líticos. La distribución de sus espacios, tanto habitacional y agrícola, son muestras de una ocupación planificada, conformándose dentro de los límites naturales y protegidos estratégicamente.

Estado de conservación: En mal estado.

Tipo de sitio: Centro Poblado fortificado con edificación doméstica.

\section{QOLLQE PEDRO}

Coordenadas UTM: 0616403 Este y 8511048 Norte a 3,920 m.s.n.m.

Ubicación: Se ubica en la margen derecha del río Qaqamarca, al noreste de la plaza principal de la comunidad de Manzanayoq (Concepción-Vilcashuamán) y al sureste de la comunidad de Ccaccamarca. Se llega al lugar tomando el camino de herradura que se dirige de Ccaccamarca hacia Manzanayoq, a la altura del sitio arqueológico Polasco tomar un desvío que asciende cuesta arriba hasta el lugar indicado.

Descripción: Se sitúa en la parte más elevada del sitio, donde aparecen recintos aglutinados de planta circular, en terrenos previamente preparados, para ello fue necesario los muros de contención, en algunos casos han removido la tierra y muchas de ellas están adosadas unos de otros por lo que posiblemente estas viviendas pertenecieron a una sola familia. En la superficie se observó una gran cantidad de material cultural como cerámica fragmentada de filiación Chanca y artefactos líticos. Qollqepedro es el único sitio donde los recintos habitacionales están mejor conservados.

Los recintos: Están representados por un conjunto de estructuras de planta circular en mal estado de conservación, los diámetros varían de 3.0 a $6.0 \mathrm{~m}$ con $0.50 \mathrm{~m}$ de alto. Además de algunos muros de contención de $5.0 \mathrm{~m}$ de largo x $1.20 \mathrm{~m}$ de alto y $1.5 \mathrm{~m}$ de espesor de muro. (Figura 21)

Murallas y zanja defensivas: Se ha descrito una muralla de $1.0 \mathrm{~m}$ de alto y de $1.0 \mathrm{~m}$ de espesor, las cuales son componentes arquitectónicos característicos de los asentamientos tardíos y las que cumplieron funciones defensivas. La zanja tiene $5.0 \mathrm{~m}$ de ancho. 


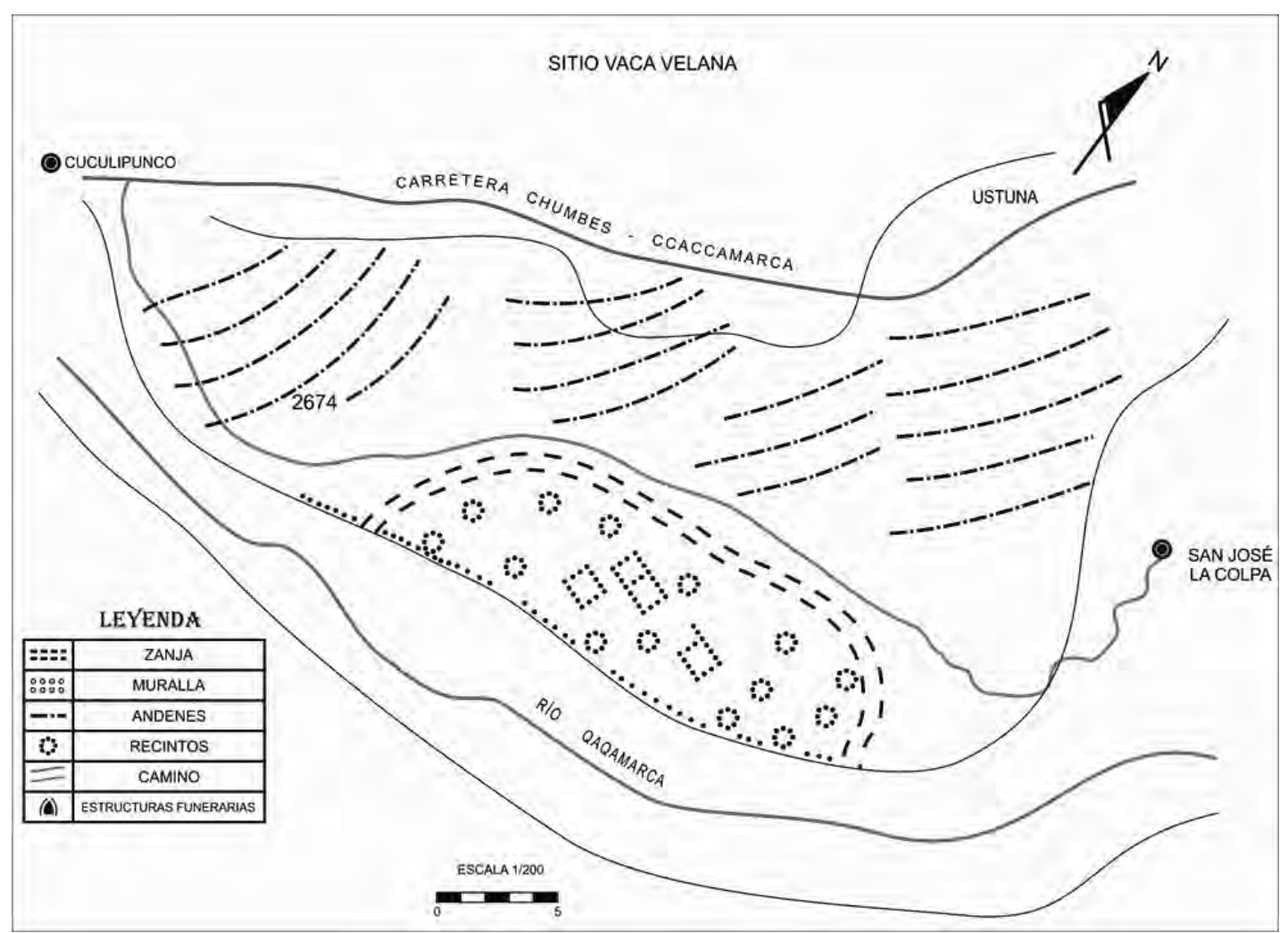

Figura 19: Croquis del sitio Vaca Velana.

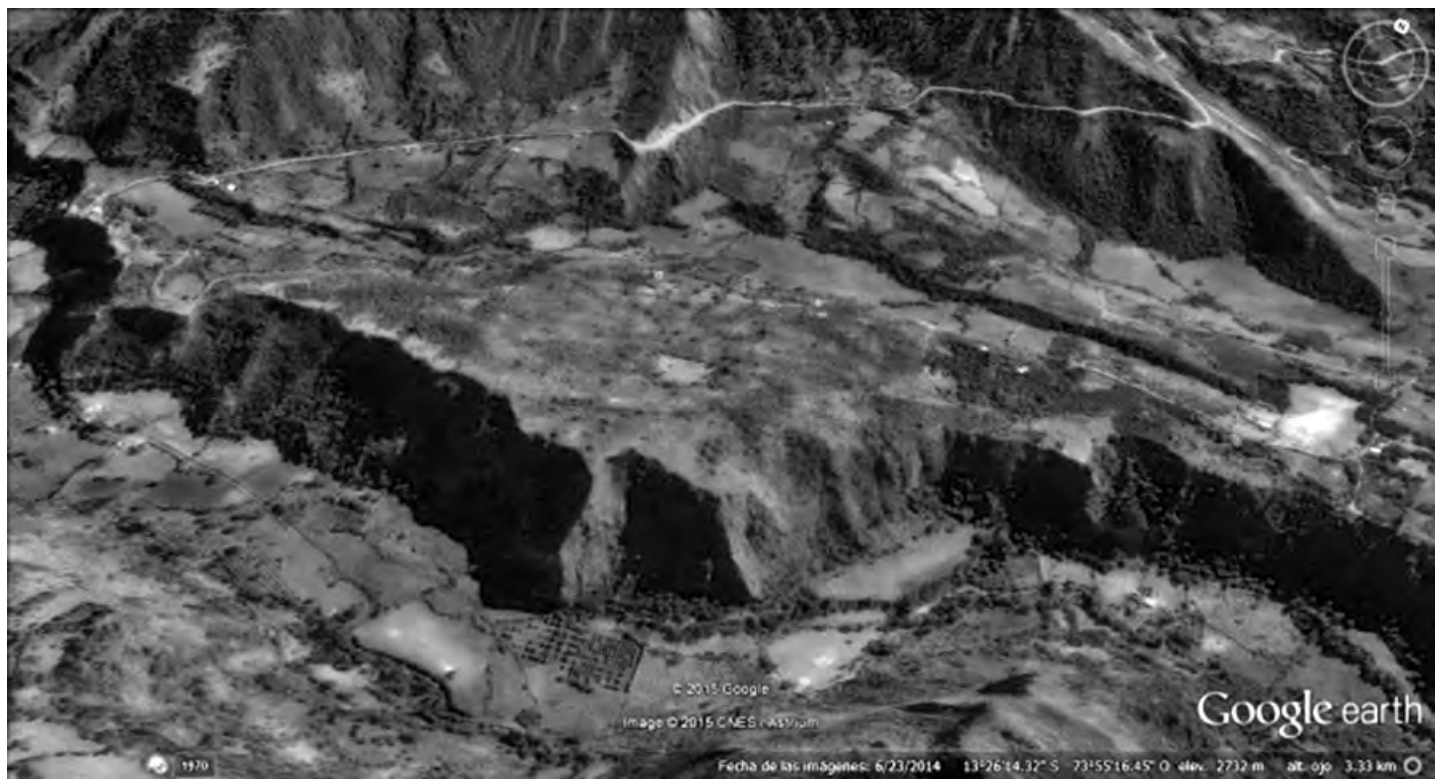

Figura 20: Vista panorámica del sitio epónimo. (Google Earth) 
Espacios funerarios: En la falda del cerro se ha podido ubicar una gran cantidad de abrigos rocosos en cuyos espacios internos se hallan restos óseos desarticulados, algunos cráneos con deformación fronto-occipital tubular.

Estado de conservación: Los recintos domésticos y defensivas se conservan en mal estado. Las estructuras funerarias presentan evidencias de profanación.

Tipo de sitio: Centro Poblado fortificado con edificación doméstica.

\section{Características generales de los sitios del Periodo Intermedio Tardio del Valle de Chumbes \\ 1.- ELEMENTOS ARQUITECTÓNICOS}

La mayoría de los asentamientos del Periodo Intermedio Tardío están ubicados en áreas topográficas bastante accidentadas, por lo mismo que se puede percibir unidades habitacionales aglutinadas sin un orden definido, no existiendo evidencias de calles, vías de circulación, plazas o áreas abiertas (González et. al 1987). Los sitios situados en el valle de Chumbes, en su mayoría, presentan una arquitectura propia de los Andes, ubicados sobre relieves bastante accidentados y laderas de gran extensión, circundado por pendientes abruptas; los recintos más comunes son de planta circular situados sobre terrenos previamente preparados, siendo necesaria la construcción de terrazas acondicionadas para obtener un piso plano, que van ascendiendo de manera escalonada y sobre ellas se hallan los recintos. Se han identificado tres tipos de recintos: la primera de planta circular con un diámetro variable de 3.0 a $6.0 \mathrm{~m}$ y altura de muro de 0.80 a $0,90 \mathrm{~m}$, el espesor de muro de 0,50 a $0.60 \mathrm{~m}$; segundo, estructuras de planta cuadrangular y rectangular que por lo general se hallan anexas a los recintos circulares, cuya función estaría ligada a la administración y residencia de personalidades importantes; finalmente, los recintos hundidos, para su construcción tuvieron que cavar el suelo y cortar el talud del cerro, siendo construcciones reducidas de 3.0 a $6.0 \mathrm{~m}$ de diámetro. A ello se adhiere espacios

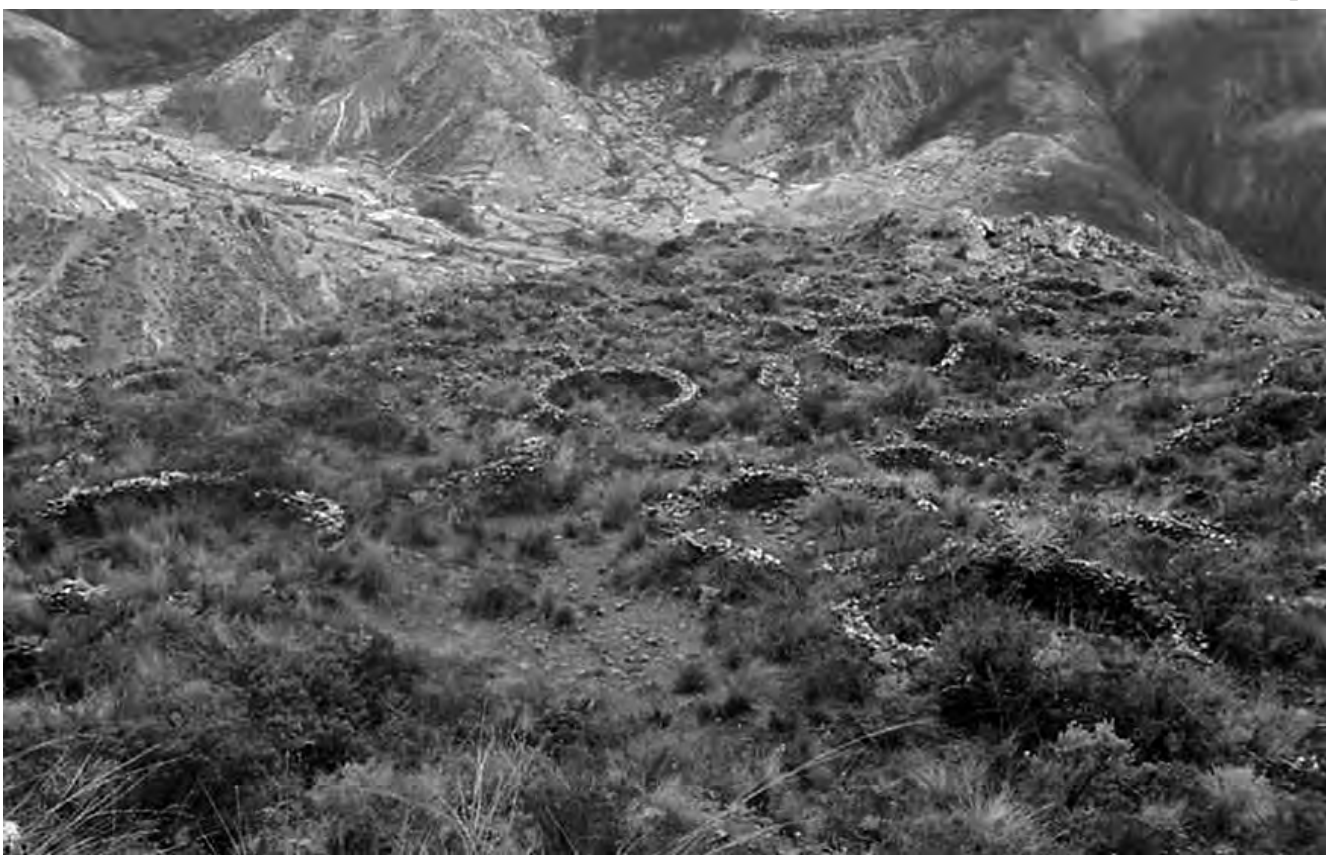

Figura 21. Vista general del sitio Qollqe Pedro, se aprecia la disposición aglutinada de los recintos. 
circulares de gran tamaño que vendrían a ser corrales, y recintos estratégicos instalados en partes elevadas ligadas a la vigilancia.

Los materiales utilizados para la construcción son principalmente de procedencia local, a base de piedras de campo previamente seleccionadas y trabajadas (González et. al 1987), unidas con barro y rellenadas con pachillas para darle mayor consistencia; los muros están dispuestos en hiladas horizontales y superpuestos uno sobre otro, cuyo paramento no presenta ningún tipo de enlucido por lo tanto es de condición ordinaria y/o simple ya que las piedras están colocadas en caras planas, buscando un aspecto estético, estos fueron unidas con argamasa de barro mezclados con fibras vegetales como el ichu (Stypa ichu) y restos de cerámica. (Figura 22-23)

Sobre las características de estas viviendas, Monzón (1965 [1586]) sugiere que: "eran bajas y pequeñas con techos a dos aguas hechas de madera e ichu"; etnográficamente el mejor testimonio se aprecia en los valles de Chumbes y Ccaccamarca, se trata de chozas o hatos ganaderos de planta circular y/o rectangular de techo cónico y a doble vertiente hechos con madera y cubierto con ichu, la puerta elaborada a base de palos o carrizos (Phragmites australis) dispuestos verticalmente y atados con soguillas de cabuya. Estas viviendas están asociadas a corrales o canchas de vacunos y ovinos (que relevaron a los camélidos); tradición prehispánica que persiste en la zona de estudio.

\section{2.- SISTEMAS DEFENSIVOS}

La mayoría de los sitios arqueológicos están delimitados por un sistema de estructuras defensivas como murallas perimétricas y profundas zanjas. Para Vivanco (2004) se trata de construcciones relacionados a la defensa artificial para la seguridad del ayllu o familia, es decir, a los integrantes de un pueblo. Algunos asentamientos como Ventanayoq, Llaqtapata (Figura 24), Llaqtapata II y Vaca Velana están fortificados con murallas perimétricas y profundas zanjas: se percibe en los sitios una a tres murallas irregulares y en mal estado de conservación, las murallas miden de 5.0 a $17.0 \mathrm{~m}$ de largo por 1.30 a $2.0 \mathrm{~m}$ de ancho y 1.50 a $1.90 \mathrm{~m}$ de altura, construidos con piedras grandes y medianas unidas con mortero de barro.

Las zanjas miden entre 30 a $60 \mathrm{~m}$ de largo por 1.50 a $5.0 \mathrm{~m}$ de ancho y 1.30 a $2.0 \mathrm{~m}$ de profundidad, reforzados con pequeños muros para evitar deslizamientos. Esta práctica de resguardar aldeas se sistematizó en el Periodo Intermedio Tardío, cumpliendo las exigencias necesarias para impedir el acceso a las aldeas de tropas enemigas en una época de inestabilidad socio-política en la que se vivía.

\section{3.- SISTEMA AGRÍCOLA Y GANADERO}

La agricultura y pastoreo fueron la principal actividad económica de los habitantes del valle de Chumbes, sin embargo, una producción agrícola intensiva exigió la transformación del paisaje con el fin de extender las áreas de cultivo y la humedad de los suelos. Los Chancas aprovecharon y continuaron manejando la infraestructura agrícola de sus antecesores; donde sólo el riguroso aprovechamiento de recursos permitió una subsistencia no del todo azarosa (Lumbreras 1974:197). Evidencia de ello se percibe en áreas próximas a los sitios arqueológicos de Mantecayoq, Supaycancha, Muyorqo, Sungalla, Chumbes, Ccaccamarca, etc. Todos en mal estado de conservación.

3.1. Andenes. Los andenes constituyen una forma de tecnología adaptada al medio natural andino, lográndose mejor suelo, mayor fertilidad, uso racional del agua y mayor productividad (Santillana 1999: 107). Las técnicas constructivas utilizadas para preparar los andenes son bastante rudimentarias, consistiendo solamente en crear espacios escalonados (González et.al 1987: 205); estos andenes van ascendiendo de la parte baja hacia la parte alta con dimensiones variables de 15 a $20 \mathrm{~m}$ de largo por 1.0 a $4.0 \mathrm{~m}$ de ancho y 1.20 a $1.50 \mathrm{~m}$ de altura. Generalmente 

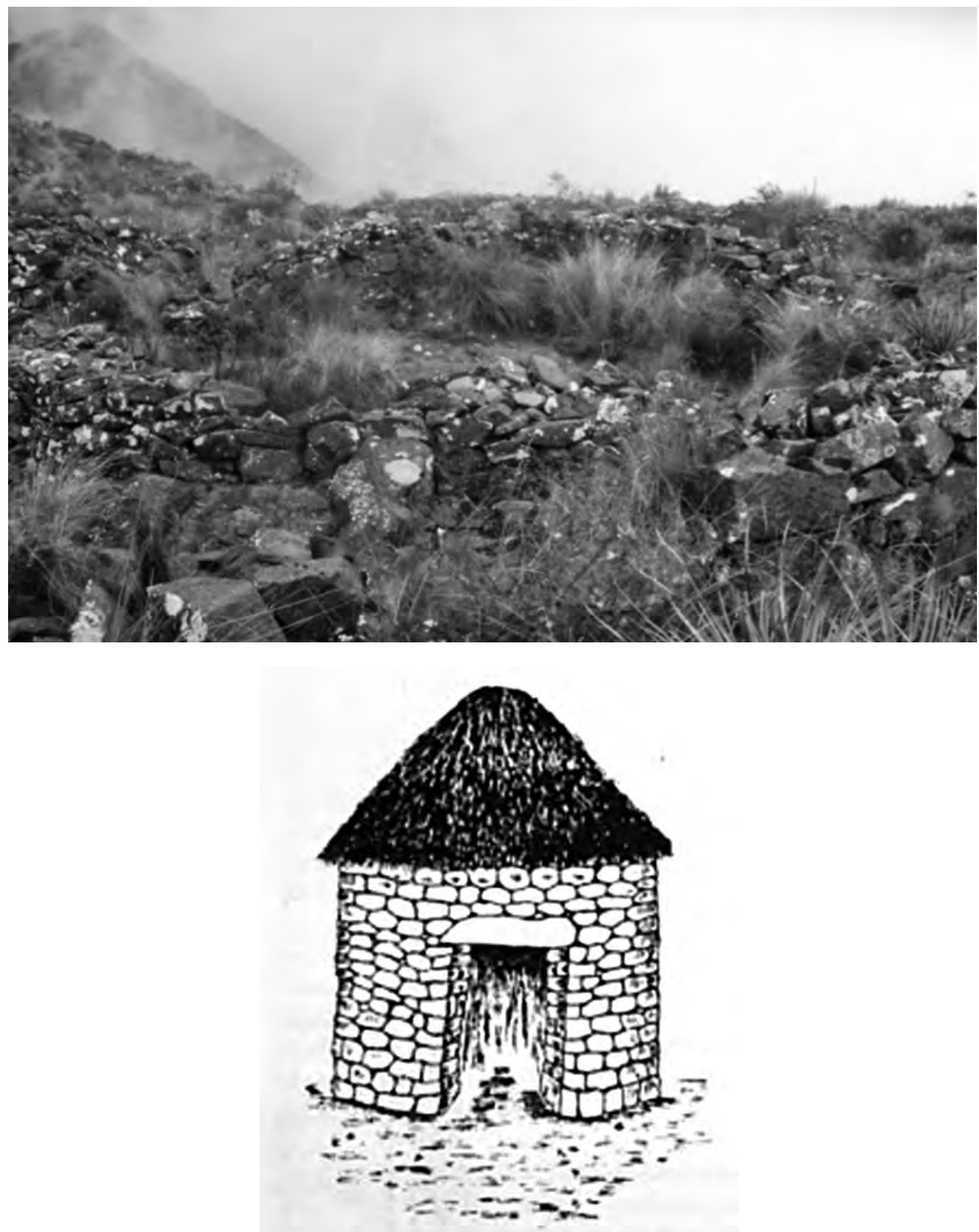

Figura 22-23. Recinto de planta circular en el sitio Qollqe Pedro. Abajo: Reconstrucción hipotética. 


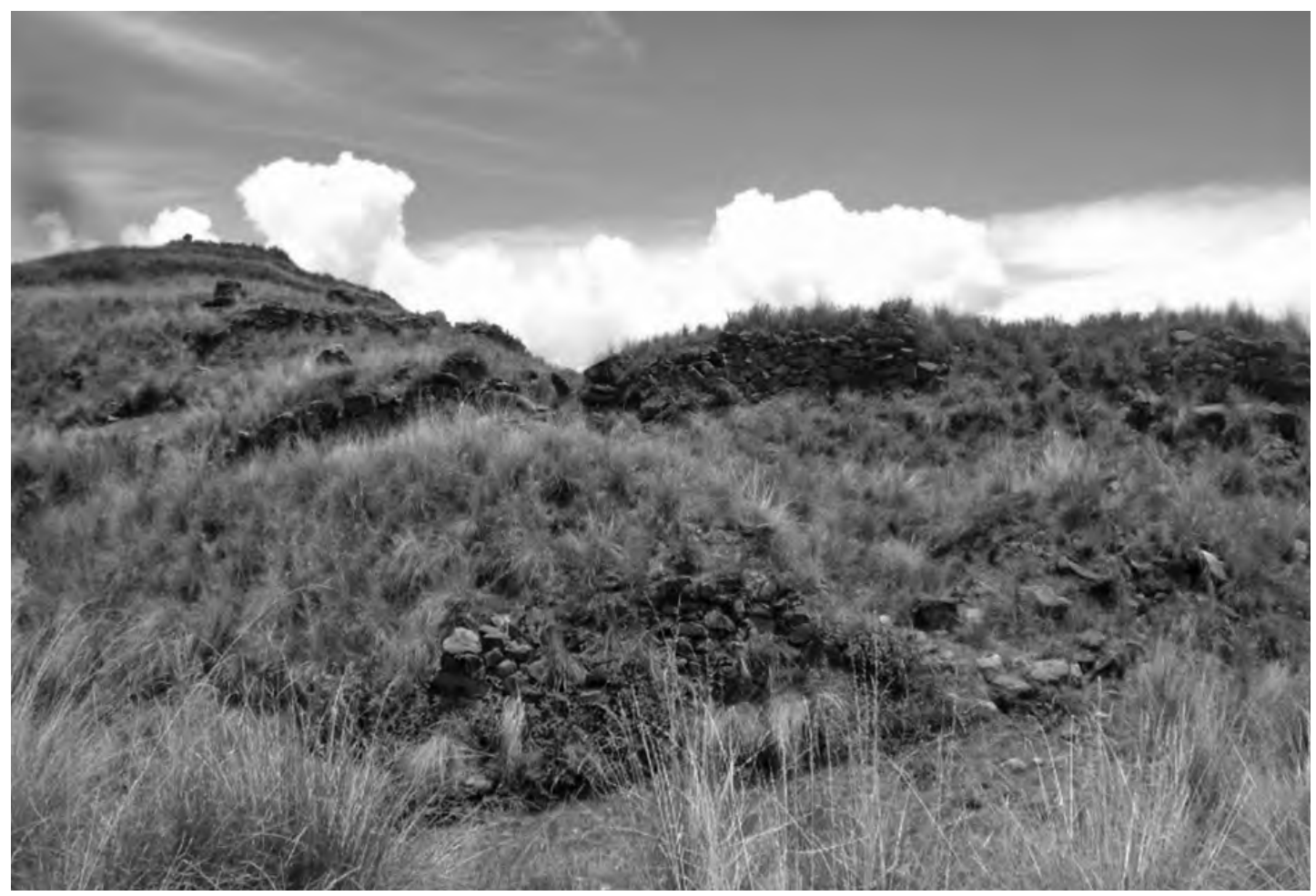

Figura 24. Tres murallas defensivas que circundan el sitio arqueológico de Llaqtapata.

los muros fueron construidos con piedras de tamaño mediano y colocadas en hiladas horizontales, superpuestas una sobre otra obedeciendo en sus formas a la topografía del terreno; en algunos casos estos muros están unidos con argamasa de barro, muy probablemente sea de épocas precedentes a la ocupación Chanca. (Figuras 25-26)

En los extremos de las terrazas se hallan piedras verticales delimitando cada uno de los espacios agrícolas, y sobre las zonas eriazas (grandes rocas) se disponen amontonamientos de piedras menudas, la misma que es evidencia del constante mantenimiento y limpieza antes del inicio de las labores agrícolas. Finalmente, no hemos identificado escaleras asociadas a estas estructuras, pero sí, una considerable cantidad de azadas fragmentadas.

3.2. Canales de irrigación. En el valle de Chumbes el porcentaje de tierras modificadas por el sistema agrícola prehispánico es muy elevado. Es resultado de un conocimiento que consistió en la modificación del paisaje natural a cultural; hoy en día estos espacios agrícolas se mantienen en desuso y en mal estado de conservación, y otros se perciben en los cortes de la carretera y caminos. Se han identificado algunos canales deteriorados sobre la falda de los cerros y anexas a los andenes agrícolas de los sitios de Supaycancha, Majuelo y Sungalla. Los muros laterales alcanzan hasta $0.40 \mathrm{~m}$ de ancho y $0.20 \mathrm{~m}$ de alto visible, fueron construidos con piedras semicanteadas del lugar unidas con barro para cubrir los espacios pequeños. Este sistema permitió que las aguas discurrieran uniformemente, transportaron este recurso desde el reservorio de Cochas, mediante esta técnica practicaron una agricultura con riego y en secano. En definitiva, el sistema de canales fue intensamente utilizado en épocas precedentes a los Chancas y reutilizados en el Horizonte Tardío, y periodos colonial y republicano. 
3.3. Corrales ganaderos. Los cimientos de grandes corrales asociados a pequeños recintos de planta circular fueron hallados en los sitios arqueológicos de Huayna Pizarro y Balcón, ubicados en zonas de extensa planicie altoandina con un clima frío que fue fundamental para la reproducción y crianza de camélidos. Los corrales son de forma circular de 18.0 a $20.0 \mathrm{~m}$ de diámetro por $0.70 \mathrm{~m}$ de ancho, con elevaciones superiores a $0.80 \mathrm{~m}$. Para su construcción se utilizó piedras de tamaño mediano pircado en seco, es decir, no utilizaron barro para unirlas; por lo tanto no tiene un buen acabado técnico. En estos corrales se habrían albergado un buen número de camélidos como la llama (Lama glama), alpaca (Lama pacus) y probablemente la vicuña (Vicugna vicugna); estos animales eran muy requeridos para el transporte, la confección de vestimentas y alimentación, complementando con la crianza del cuy (cavia porcellus) cuyos restos han sido identificados en el sitio de Ventanayoq. (figura 27-28)

Hoy en día, cerca de estos corrales prehispánicos, la comunidad de Ocros ha impulsado la crianza de vicuñas con la finalidad de aprovechar su lana, llevando acabo el respectivo Chaqu o chaco en el mes de junio. Y en las periferias, los pobladores complementan con la crianza de ganados vacunos, ovinos, porcinos y caballares.

\section{4.- VIAS DE COMUNICACION}

4.1. Los caminos. Constituyeron una vía primordial de comunicación de vital importancia para interconectar los poblados, huacas o santuarios y traslado de las personas de un lugar a otro. En el valle de Chumbes existen tres tipos de caminos: primero, una vía principal que viene a ser un ramal del Qhapaq Ñan; segundo, son los caminos zonales, y por último los caminos locales. El camino principal también conocido como Qhapaq Ñan, Qatun ñan o Inka Ñan, recorre transversalmente por el valle y cubre una extensión aproximada de 18 km (desde el río Pampas hasta la cumbre de Pumaqawanqa) y va en dirección suroeste a noreste. Esta vía se dirige desde Andahuaylas hacia Ayacucho cruzando por los actuales territorios de Uripa, Chincheros, Ahuayro, el puente sobre el río Pampas, Ninabamba, Pajonal, Ibias, Arccacc, Ocros, Jacaspampa y Pumaqawanqa (muy cerca del ushnu epónimo). Este camino tiene un ancho aproximado de $3.0 \mathrm{~m}$ y se desplaza principalmente por la falda de los cerros para lo cual fue necesario obtener un piso plano mediante muros de contención de tamaño variado que va desde 0.80 a $1.20 \mathrm{~m}$. En los lugares rocosos se picaron las piedras formando una especie de graderías, en algunos casos los peldaños están construidos con piedras planas, los pasos son anchos entre 0.30 a 0.50 $\mathrm{m}$. Son notorias aun las piedras que delimitan el camino. Actualmente solo son reutilizados algunos tramos de este importante camino prehispánico. (Figuras 29-30)

Los caminos zonales o secundarios, se trata de una vía de circulación interna dispuestos con la finalidad de articular los principales poblados y áreas adyacentes del valle de Chumbes. Uno de los tramos de estos caminos se desplaza muy cerca de los sitios arqueológicos del Periodo Intermedio Tardío; está construido sobre la falda de los cerros que delimitan los territorios de las comunidades situadas en el valle de Chumbes. El camino presenta muros de contención, con secciones encajonadas y de pendiente relativamente llana, tiene $2.0 \mathrm{~m}$ de ancho en promedio y cubre una distancia de $6 \mathrm{~km}$. El camino une a las actuales comunidades de Ninabamba, Pajonal, Chumbes y Ccaccamarca, a ello se conectan varios caminos transversales que se dirigen a los pequeños caseríos. Vías que fueron utilizados con gran frecuencia desde épocas prehispánicas hasta la actualidad por lo que se hallan en buen estado de conservación.

Caminos locales, además de los caminos antes mencionados se pudo divisar un gran nú- 

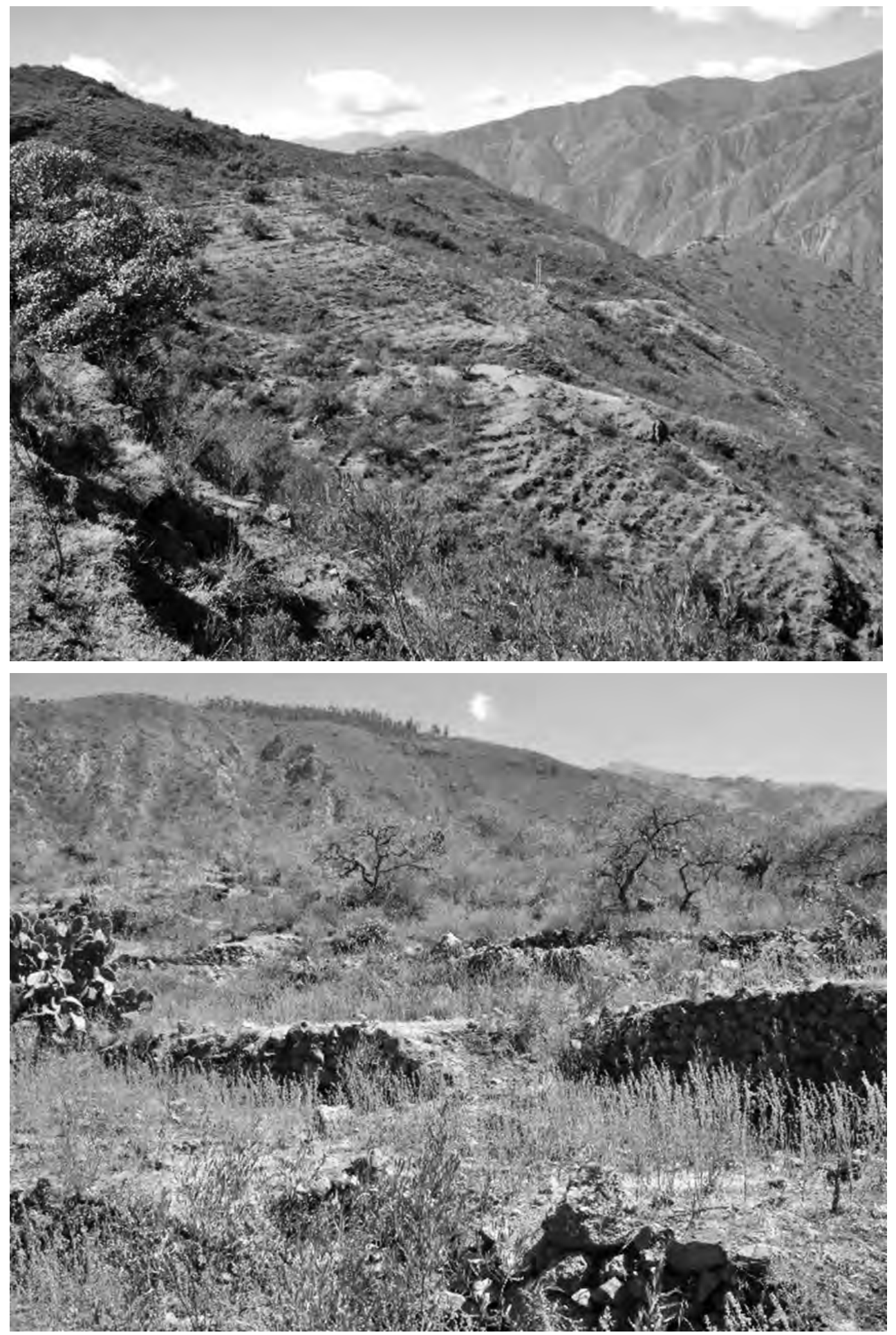

Figuras 25, 26. Sistema de andenerías asociadas a canales de irrigación hallados en los sitios arqueológicos de Sungalla y Supaycancha. 

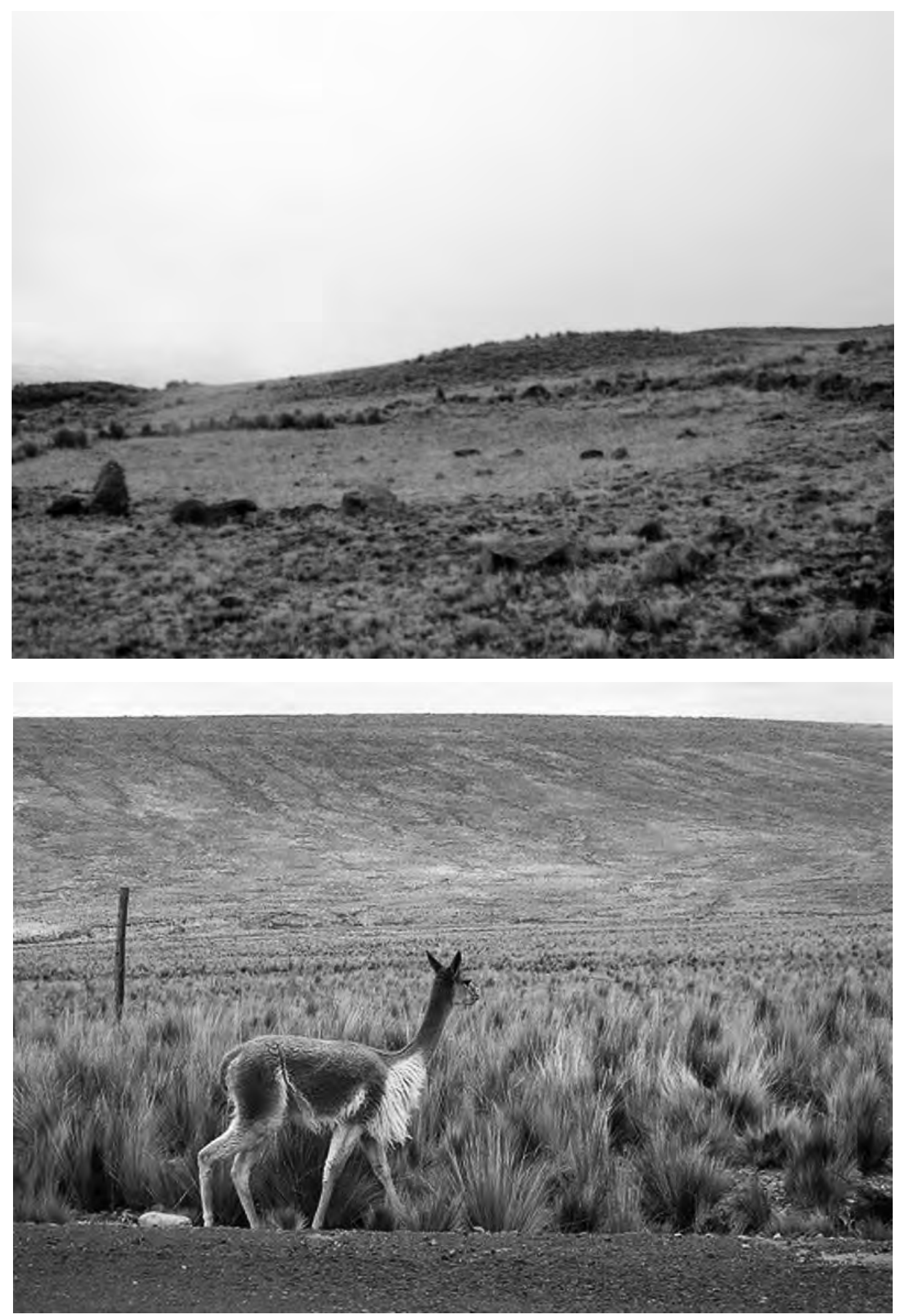

Figura 27-28: Corral circular y criadero de vicuñas en las altipampas de Huayna Pizarro y Tintaypampa. 
ser bastante estrechas que básicamente permitían la circulación intra e inter sitio. El mejor testimonio de esta vía se aprecia en el trayecto que une los sitios de Ventanayoq y Llaqtapata, Laqtapata II e Ibias, etc. Se mantienen en mal estado de conservación.

\section{5.- ESTRUCTURAS FUNERARIAS}

"Una estructura funeraria es el espacio físico que contiene elementos como el individuo y los objetos asociados, que pueden estar ubicados en espacios naturales o artificiales, subterráneos, a flor de tierra o aun sobre elevado" (Kaulicke 1997, p.25). Partiendo desde este punto pasamos a describir algunos tipos de entierros localizados en los sitios del Periodo Intermedio Tardío del valle de Chumbes.

5.1. Abrigos rocosos. Se trata de cuevas de los afloramientos rocosos poco profundos donde la medida de la entrada de ingreso es menor que su altura, ubicados en zonas completamente empinadas y medianamente accesibles, asociados a un conjunto de enormes rocas desprendidas. Los espacios internos fueron acondicionados de acuerdo al relieve del abrigo donde se hallan un conjunto de osamentas desarticuladas que muestran los cráneos con signos de trepanación y huellas de fracturas antemorten, y otros con deformación oblicua fronto-occipital tubular. Definitivamente se trata de entierros colectivos asociados a un ajuar funerario muy pobre y reducido a objetos de cerámica y textiles (González et. al 1987; García 2009). En el sitio de Ventanayoq pudimos identificar un abrigo rocoso conteniendo entierro del periodo Wari asociado a otros de la época Chanca, lo que indica que hubo una reocupación ulterior. (figuras 31 y 32 )

5.2. Las chullpas. Sobre la cima del cerro Balcón hemos identificado los cimientos de un conjunto de chullpas bastante destruidas. Construidas a base de piedras canteadas unidas con argamasa y asociados a pequeños espacios abiertos; el diámetro de la base alcanza los $2.0 \mathrm{~m}$ y $0.90 \mathrm{~m}$ de espesor del muro. Su condición deteriorada ha imposibilitado apreciar en su totalidad sus características particulares. (figura 9)

Estas estructuras datan del Periodo Intermedio Tardío, es muy posible que hayan tenido similitudes con las chullpas halladas en el distrito de Concepción -área cercana al valle de Chumbes- por Ochante (2001: 52) quien indica que "se tratan de estructuras de planta circular de 2.0 a $2.30 \mathrm{~m}$ de ancho por 1.0 a $1.50 \mathrm{~m}$ de altura y cuyo techo adopta una forma de falsa bóveda que unido al barro va formando un cono; encima del muro que soporta el techo, se hallan predios alargados en forma de jambas que permitían sostener estas estructuras".

5.3. Las cámaras funerarias. Gran parte de estas estructuras se localizan en los sitios de Huayna Pizarro y Ventanayoq que datan del Periodo Intermedio Tardío. En el primer sitio se hallaron cámaras disturbadas de planta semicircular y cuadrangular adosadas a la pared vertical del acantilado (cantera de andesita). Las cámaras tienen dimensiones entre 1.70 a 2.0 m y 0.70 a $0.90 \mathrm{~cm}$ de espesor de muro, construidos con lajas de andesita unidos con barro, la planta interna es semicircular en forma de "D". El aparejo interno y externo son ordinarios con piedras sobresalientes y las paredes se inclinan ligeramente hacia el interior. El espacio interno exhibe restos óseos desarticulados obedeciendo a entierros colectivos. En mal estado de conservación. (figura 34)

En el sitio de Ventanayoq hemos registrado una cámara rectangular debajo de una enorme roca de $6.0 \mathrm{~m}$ de alto, está cimentada con piedras de campo y unidas con argamasa de barro. El acabado de sus muros es de aparejo simple, cuyas dimensiones son de $1.50 \mathrm{~m}$ de largo x 1.30 $\mathrm{m}$ de ancho, $0.80 \mathrm{~m}$ de espesor y $0.80 \mathrm{~m}$ de alto. Además se halló una cámara dentro de una roca de $4.0 \mathrm{~m}$ de alto, tiene una forma circular de $2.10 \mathrm{~m}$ de diámetro por $1.20 \mathrm{~m}$ de alto. En los espacios internos se hallaron escaso material óseo, al parecer habría estado destinado a entierros individuales. (figura 33) 

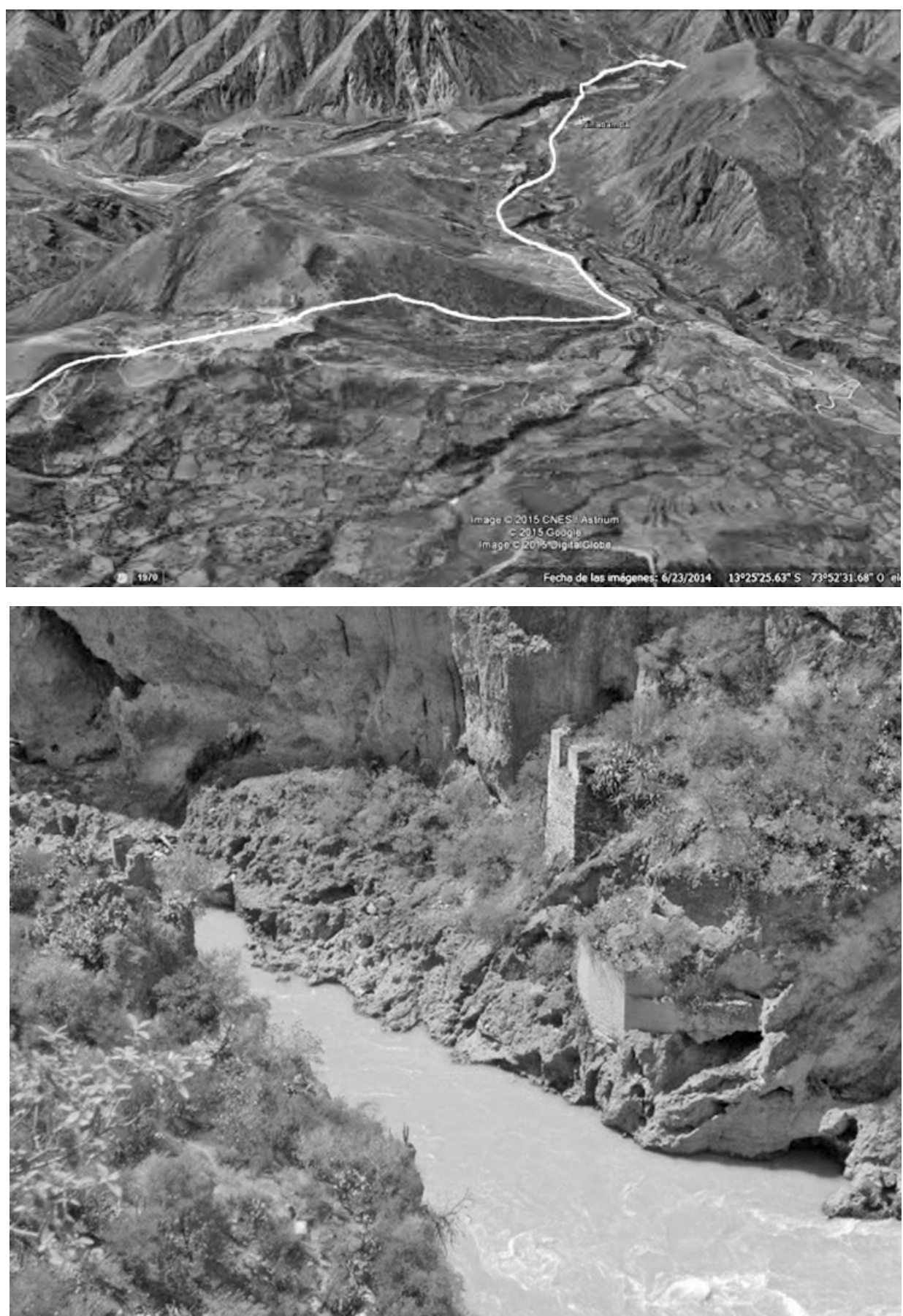

Figura 29-30: Recorrido del camino prehispánico o Qhapaq Ñan por el valle de Chumbes. Fuente Google Earth. Abajo: estribos del antiguo puente colgante sobre el río Pampas. 

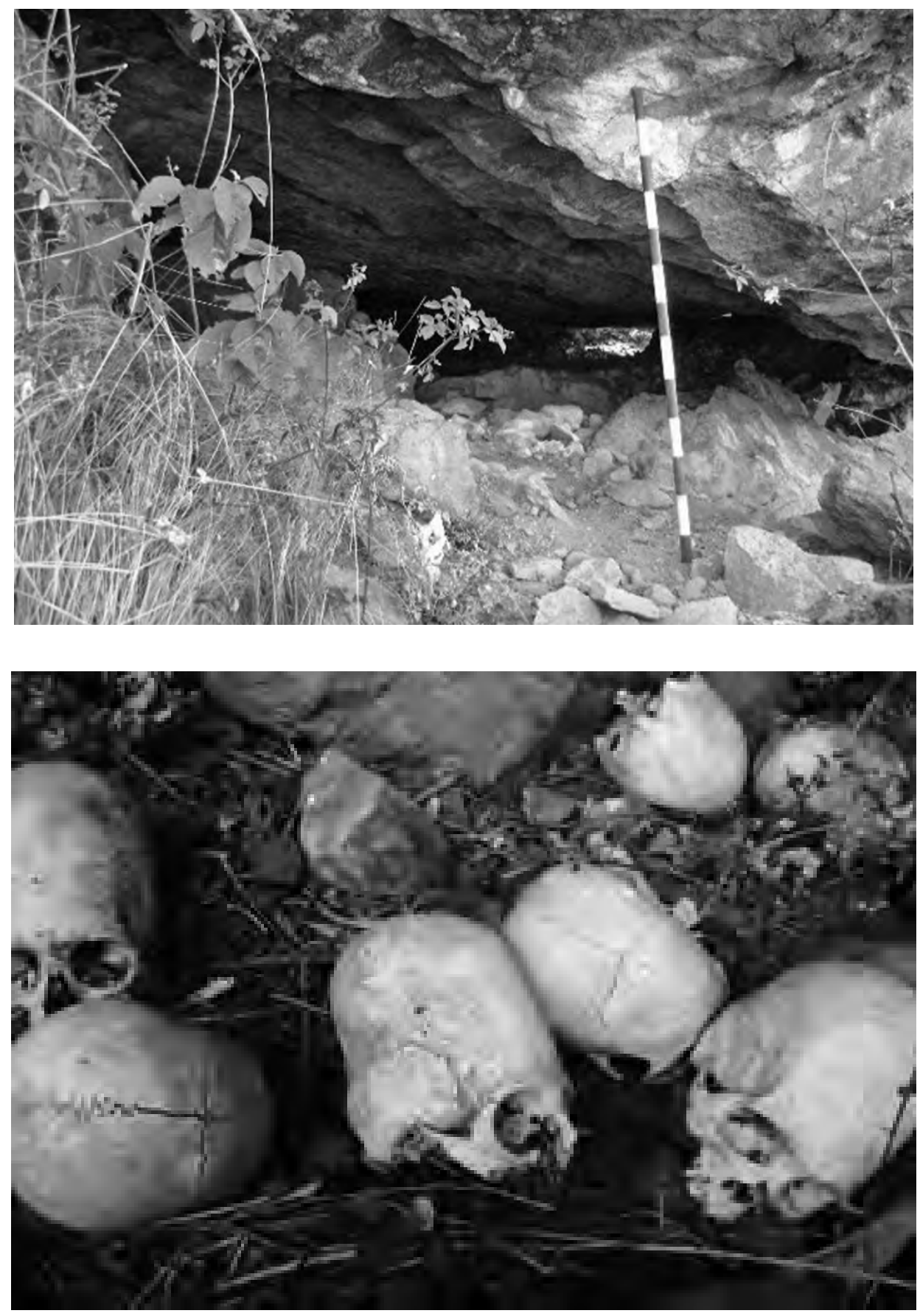

Figura 31-32: Abrigo rocoso donde se hallaron cráneos con signos de trepanación y huellas de fracturas antemorten $y$, otros con deformación oblicua fronto-occipital tubular. Sitio Ventanayoq 

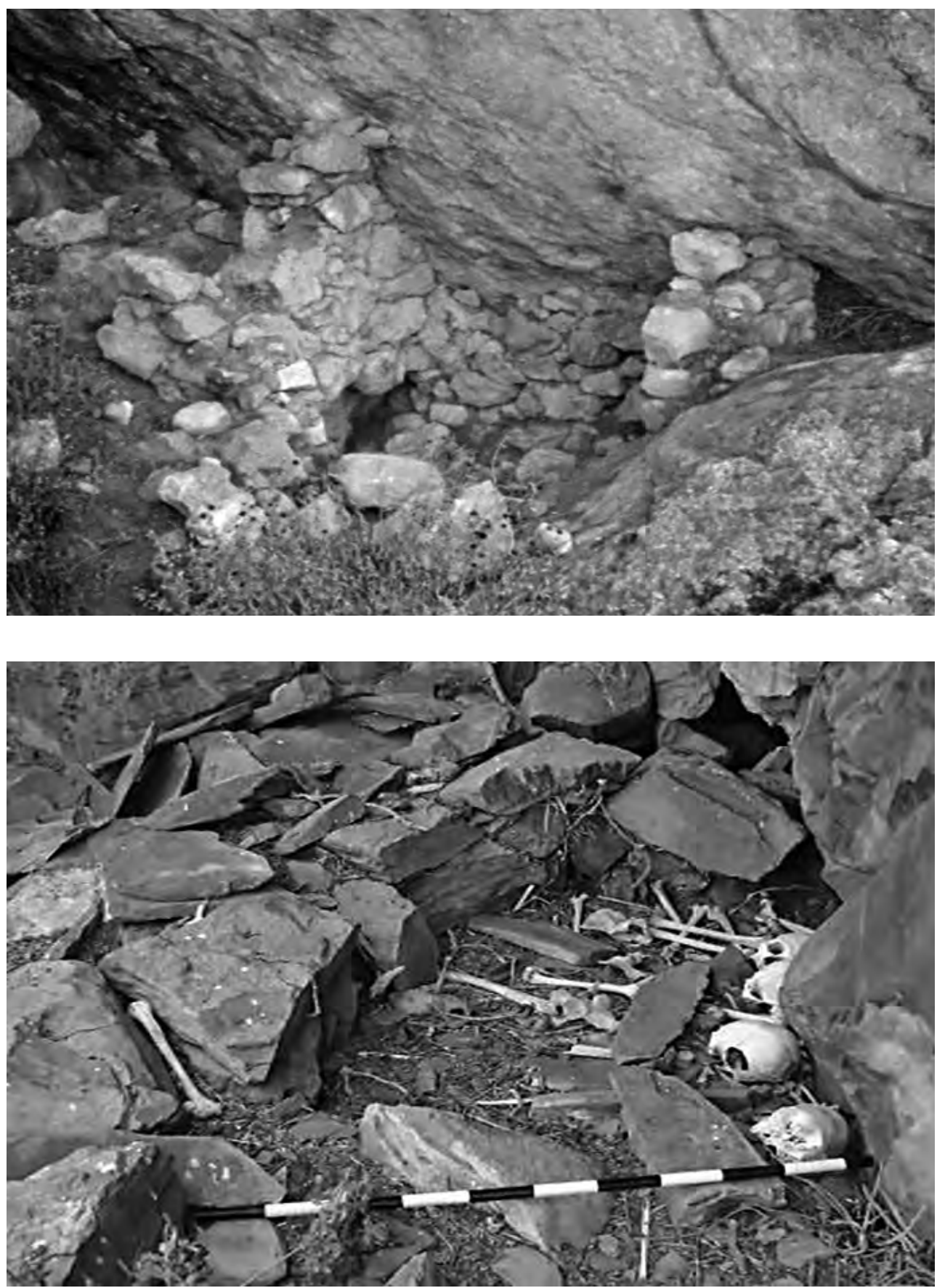

Figura 33-34: Cámara funeraria en Ventanayoq. Restos óseos al interior de la cámara en Huayna Pizarro. 


\section{6.- MATERIAL CULTURAL ASOCIADO}

En todos los sitios arqueológicos registrados pudimos observar una gran cantidad de material cultural en superficie, predominando los fragmentos de cerámica de clara filiación Chanca, además de artefactos y deshechos líticos.

La cerámica. De todos los sitios se ha tratado de recolectar fragmentos diagnósticos de superficie de acuerdo a las diferencias en forma, función y aspectos estilísticos. Metodológicamente para la recolección y registro se ha ejecutado un muestreo aleatorio simple partiendo de la sectorización y clasificación de los componentes arquitectónicos y espaciales; recogiendo el material arqueológico de los recintos y espacios asociados. La cerámica recolectada de los asentamientos del Intermedio Tardío del valle de Chumbes, según la clasificación de Lumbreras (1974) y González et. al (1987) corresponden a los estilos Tanta Orqo, Qachisqo, Arjalla y Aya Orqo; de características sencillas y elaborados con una tecnología bastante simple. El alfar Chanca fue analizado a partir de criterio morfo-funcional, tecnológico y la asociación rasgos.

La cerámica ha sido un indicador que ha proporcionado mayores evidencias con respecto al territorio ocupado por los pueblos Chancas, responde a una tradición que se expresa en un patrón de elaboración, y que la existencia de grupos diferenciados se produce por variación de características, sin abandonar el patrón de manufactura (González et. al 1987, p.38). Se ha identificado algunas formas más comunes dentro del material cerámico perteneciente a este período, siendo los bordes de ollas el de mayor porcentaje seguido por cuencos, platos, cántaros y escudillas, los cuales presentan un acabado medianamente tosco y una decoración pictórica post cocción. De acuerdo con el análisis de la pasta y sus inclusiones se puede suponer que la materia prima es local, acarreadas desde las canteras de arcilla ubicadas en Ccaccamarca, Erapata, Sungalla, Jacaspampa y Lucería, mientras que del yacimiento Huachuya extrajeron los insumos para el decorado pictórico.

Lumbreras (1974, p.218) menciona que en el curso del bajo Pampas y en la región de Ocros y Uripa, ha identificado colecciones de cerámica correspondiente al patrón Arjalla, además supone que estamos frente a una etnia más o menos uniforme. En efecto, el material predominante en los sitios Chanca del valle de Chumbes es justamente el grupo Arjalla (Figura 35), mostrando formas y funciones variadas. Se trata de una cerámica de apariencia tosca y rudimentaria con una superficie irregular, la decoración está basada en aplicaciones plásticas e incisiones, pintadas a base de líneas y chorreado de color rojo diluido; la manufactura es modelada, la cocción se realizó en atmósfera oxidante y reductora (González et. al 1987: 39, García 2009: 104).

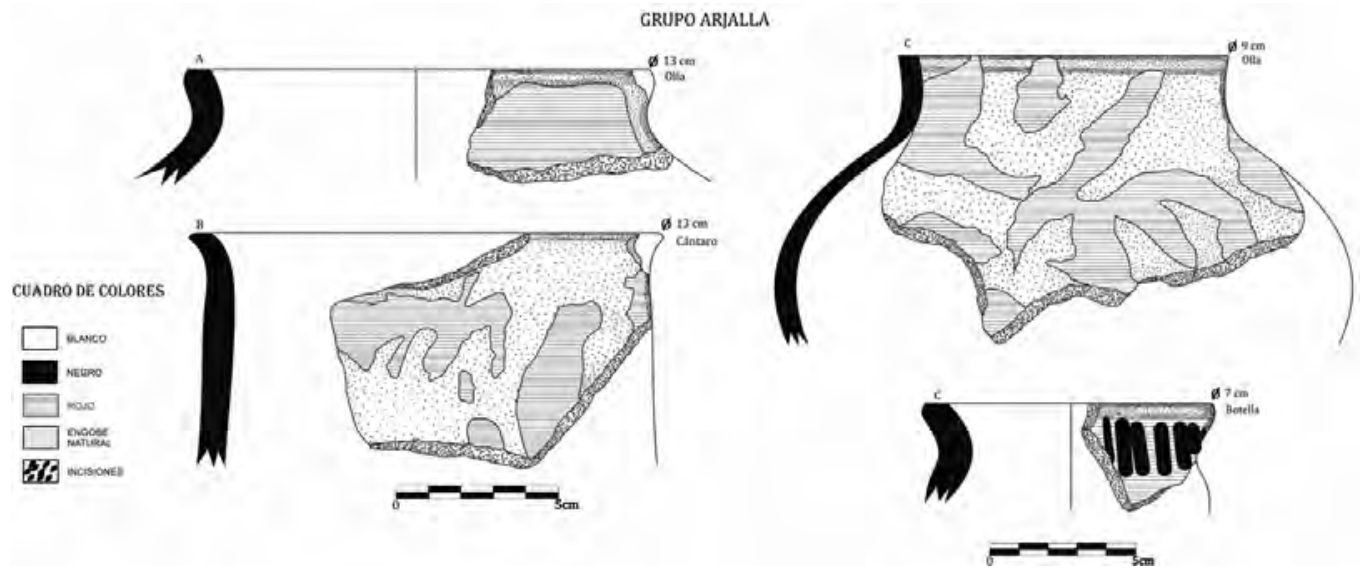

Figura 35: Formas reconstruidas de cerámica pertenecientes al grupo Arjalla. 
El segundo grupo preponderante es el alfar Tanta Orqo (figura 36), el más temprano y con ciertas afinidades con el estilo Wamanga del Horizonte Medio. Tanta Orqo sería una manifestación del abandono progresivo de las tradiciones previas para dar paso a la consolidación de manifestaciones estilísticas propiamente Chancas (González et. al 1987: 39). Se trata de una cerámica de apariencia ligeramente tosca, decoradas a base líneas, bandas, manchas y puntos de color negro, rojo ocre y marrón. Los fragmentos de este grupo fueron hallados en los sitios cercanos a espacios agrícolas y menos agrestes del valle, lo que supone que inicialmente los grupos rurales no abandonaron por completo los asentamientos de su antecesor Wari, sino que paulatinamente fueron retirándose a las áreas cercanas en donde pudieron estar más protegidos.

El tercer y cuarto grupo están representados por los alfares Qachisqo y Aya Orqo, su distribución está evidenciado en las zonas de Huamanga, Huancavelica, Andahuaylas (González et. al 1987) y Huanta (Valdez 2003). Qachisqo se caracteriza por su monocromía, presentando la superficie de los objetos de color ante; pudo haber tenido una función particular o de culto (González et. al 1987, p 39). Los fragmentos presentan una pasta de color marrón, de textura semicompacta, el acabado superficial alisada y ligeramente pulida y, engobadas de color mate y con incisiones. La pasta tiene ciertas similitudes con el alfar Aya Orqo, sin embargo, este último muestra una técnica de manufactura superior en relación a los demás grupos, mostrando una superficie rojiza, decorada con líneas negras y blancas formando un área reticulada, teniendo varias formas en común con la cerámica incaica (Lumbreras 1974; González et. al 1987). Los fragmentos de estos estilos fueron hallados en los sitios de Vaca Velana, Cuncalla, Llaqtapata, Ventanayoq y Chumbes, lugares donde se percibe una reocupación incaica.

Probablemente hubo una distribución estandarizada de la cerámica que obedeció a un trasfondo político y religioso, sino como se explica el grado de recurrencia estilística a lo largo de la cuenca del Pampas; expresando la iconografía alfarera como instrumento de difusión, o quizás como una forma de exteriorizar la aceptación de la nueva autoridad y la adhesión a su ideología (Matos 1999: 162).

En conclusión, los fragmentos de cerámica hallados en la zona de estudio exhiben características comunes con los grupos estilísticos atribuidos al grupo Chanca (figuras 37-38), y que solo futuros trabajos ceramográficos acompañados de excavaciones arqueológicas determinarán con mayor claridad su real correspondencia.

Finalmente, se ha observado de la presencia artefactos y desechos de obsidiana, basalto, andesita y granito, en su mayoría son morteros, moliendas y puntas de proyectil.

\section{7.- ASPECTOS IDEOLÓGICOS}

Los Chancas organizaron su actividad religiosa sin una institución especializada y sin un sistema sacerdotal conocido, se deduce porque en sus asentamientos arqueológicos no se han encontrado lugares de cultos especiales. Históricamente este grupo reconocía como paqarina de origen a la laguna Choclococha (Huancavelica), asimismo manifestaban ser descendientes del león o puma (González et. al 1987), y tenían una explicación mitológica sobre sus orígenes. Al respecto Garcilaso de la Vega (1963) menciona que: “...se jactan descender de diversos padres, unos de una fuente, otros de una laguna, otros de un collado muy alto; y cada nación tenia por Dios a lo que tenía por padre y le ofrecía sacrificio". A este relato el cronista Pedro Cieza de León (1984:234) complementa lo siguiente: "Preguntándole ya a estos Chancas que se sentían de si propios y donde tuvo principio su origen; cuentan una niñería o novela como los Xauxa, es que dicen que sus padres renacieron y salieron por un palude, llamado soclococha desde donde conquistaron hasta llegar a una parte que nombraron Chuquibamba, adonde hicieron su asiento". 
GRUPO TANTAORQO

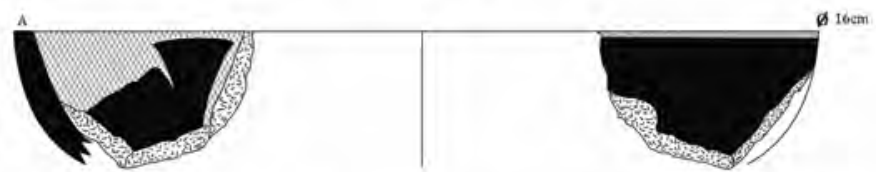

\section{CUADRO DE COLORES}

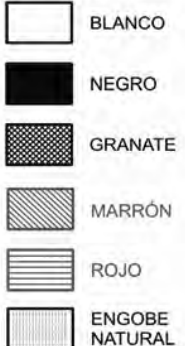

$8 \%$

FRAGMENTADO
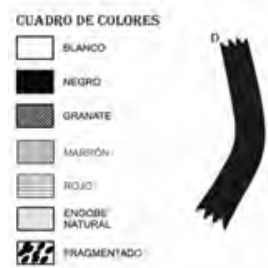
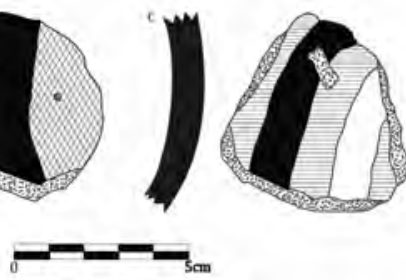

GRUPO QACHISQO

Figura 36. Formas reconstruidas de cerámica pertenecientes al grupo Tanta Orqo.

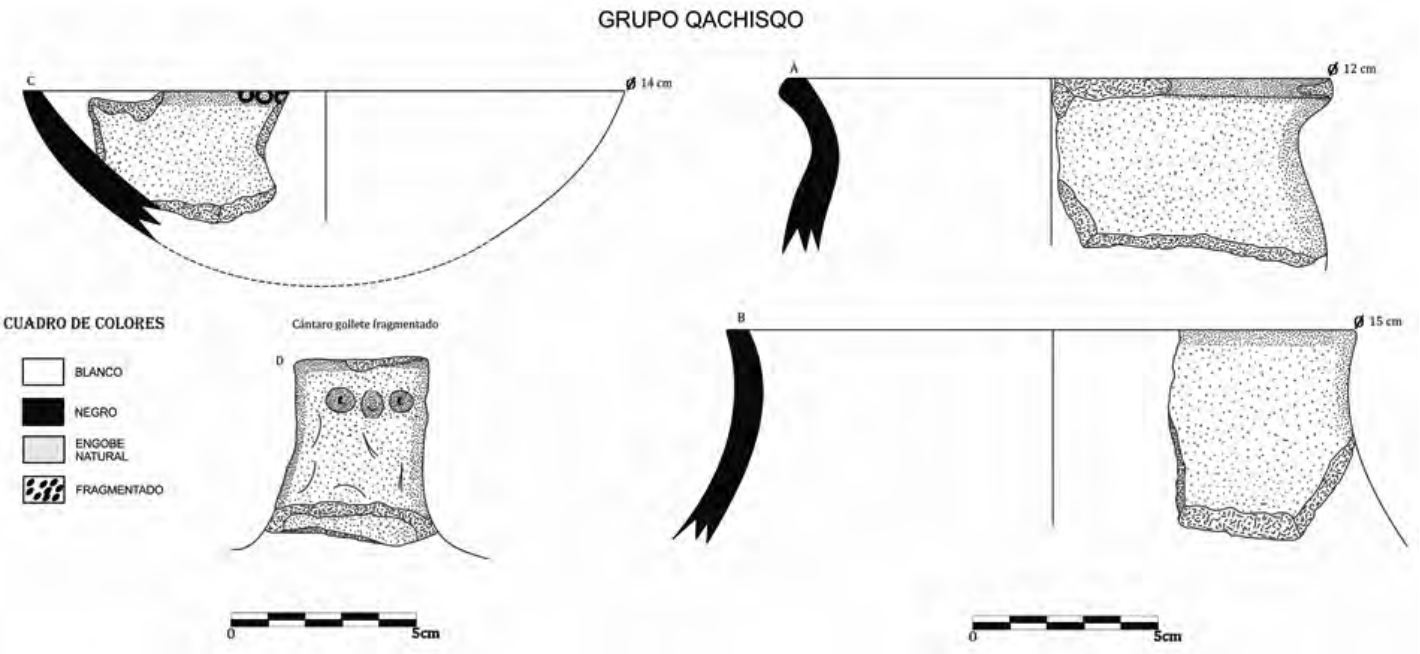

Figura 37. Formas reconstruidas de cerámica pertenecientes al grupo Qachisqo

Rindieron culto a las Huacas ${ }^{4}$ relacionadas a su cultura y practicaron ritos de amplia difusión por todo el mundo andino. Estas huacas estaban representadas esencialmente por cerros, piedras, cuevas, animales y lagunas (Figura 39) como Choclococha. Millones (1998) plantea que en las civilizaciones prehispánicas, aparte de los dioses oficiales, existía otro nivel de deidades o dioses comunales, los mismos que interactuaban cotidianamente con la población local. La expresión local en el valle de

4. La huaca es el mundo sagrado que incluye el panteón, el espacio de culto y los rituales que se realizan durante las festividades. 


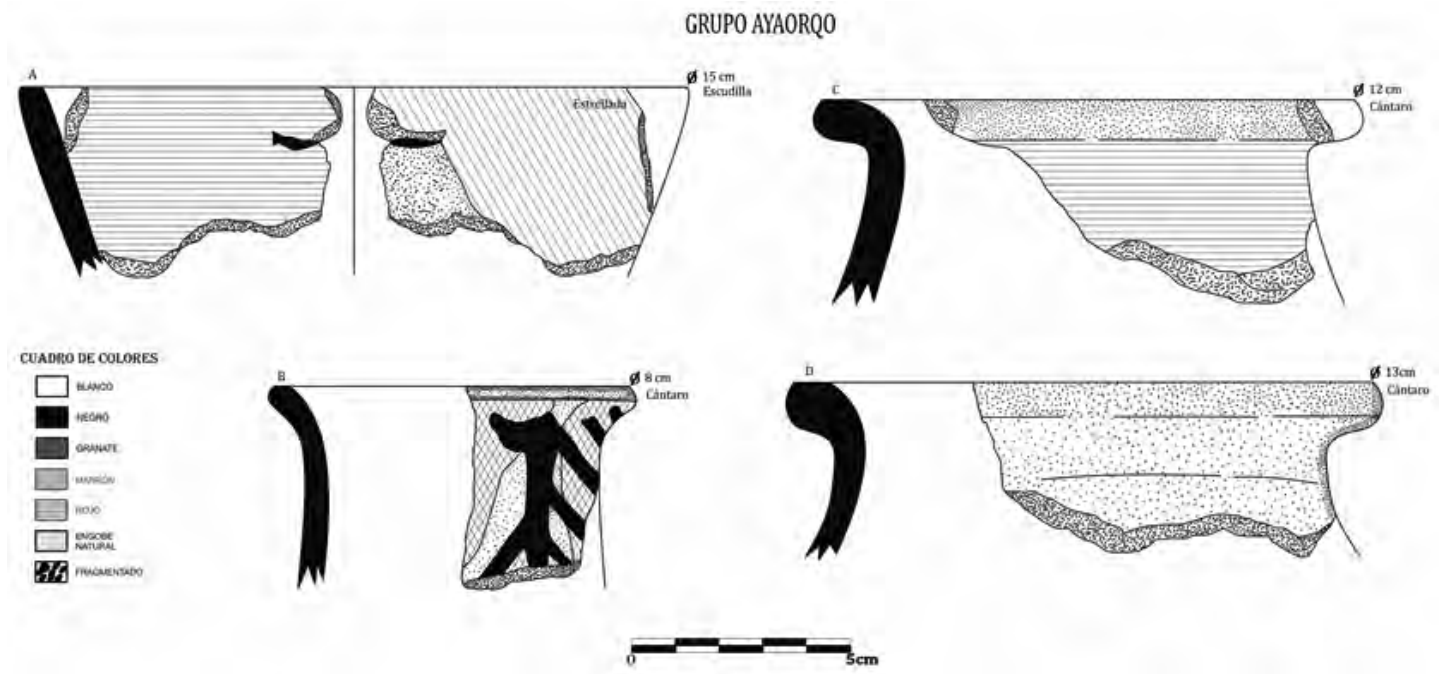

Figura 38. Formas reconstruidas de cerámica del grupo Aya Orqo.

Chumbes estaba representada por los cerros o apus como Huachuya y Huayna Pizarro (Figura 40), considerados por la población actual como montañas seculares.

Asimismo, las crónicas indican que los Chancas simbolizaban a los animales andinos, principalmente al felino y ave (puma y cóndor), y desde luego también a otros animales. Como menciona Guamán Poma de Ayala (1987 [1615]: 234) que, “...mandaban y eran muy belicosos indios, y bravos guerreros y fuertes, cada uno de ellos se embestían como leones; y si le mataban al contrario le sacaban el corazón y se comían de puro bravos". Con esta figura de puma -animal totémico- asocian a Uscovilca, al malqui de una de las dos mitades de los chancas, en concreto, de los hananchancas. Gonzales Carré (2004: 80) menciona que el vocablo uzco u ozcollo significa: felino, león andino, puma, gato cerval y/o felino salvaje; que estaría relacionado a las cualidades de Uscovilca como guerrero y cuyo nombre significa "felino sagrado". Pero no es la única figura del puma la posible representación de Uscovilca o Ancoallo ${ }^{5}$, sino también como un ave (cóndor) que formaba parte de la imagen Chanca (González 1982; Ramos 2002).

En algunos pueblos de la cuenca baja del Pampas, como Astania, Chacarí, Manzanayoq, etc. del distrito de Concepción (Vilcashuamán), así como en Ccaccamarca y Chumbes en el distrito de Ocros (Huamanga); en las festividades carnavalescas usan los usqus ${ }^{6}$ que viene a ser una reminiscencia de una tradición ancestral que data de la época prehispánica, específicamente de los Chancas. Los danzarines se cubren el cuerpo con pieles de animales como el puma, zorro, gato montés y venado, estos representan símbolos sagrados que están asociados a la destreza y la habilidad. De esa manera mantienen una costumbre ancestral y el legado dejado por los aguerridos e indómitos chancas, como sugiere Garcilaso de la Vega “...esta nación se llama Chanca, jactándose descender de un león y así lo tenían y lo adoraban por Dios, y en sus grandes fiestas, antes de ser conquistados por los reyes incas, sacaban dos docenas

5. Esta figura de 'Ancoallo' aparece en algunas fuentes como un grupo que formaba parte de la entidad sociopolítica chanca, y también como un personaje que, entre otras posibles acciones, penetró con sus gentes en la selva huyendo de los incas (Ramos 2002, p.246).

6. El usqu, es una indumentaria confeccionada con pieles de animales y comúnmente utilizada en los carnavales por los pobladores de Chumbes y Ccaccamarca en el distrito de Ocros, Huamanga. 

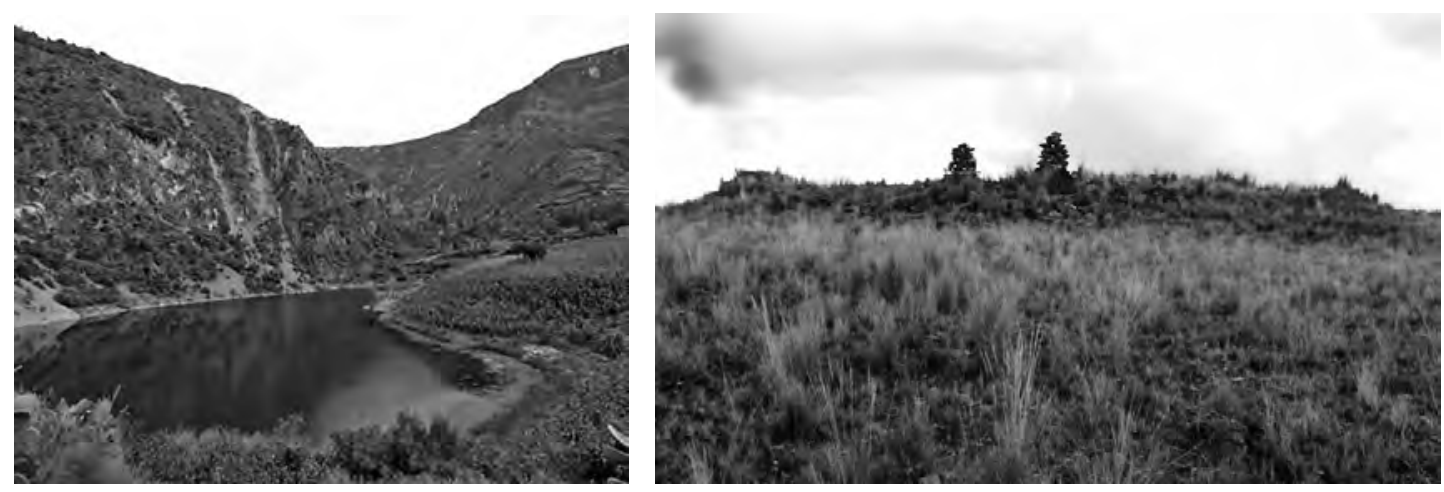

Figuras 39-40. Laguna de Angascocha en Ccaccamarca y el ushnu de Huayna Pizarro, recursos votivos de gran importancia en el valle de Chumbes. El ushnu probablemente data de épocas anteriores a los incas.

de indios de la misma manera que pintan de Hércules, cubierto con el pellejo del león, y la cabeza del indio metido en la cabeza del león; yo los vi así en las fiestas del santísimo sacramento en el Cuzco" (Garcilaso de la Vega lib. IV, cap. XV; 1963: 135).

El Carnaval se originó con la influencia de la cultura occidental, pues tomaron elementos hispanos que acondicionaron a su modo de vida tradicional, una especie de sincretismo cultural, donde se complementan la vestimenta moderna y la ancestral prehispánica (figura 42-43). También se aprecia el tradicional pukllay y warakanakuy, donde los contendores se arrojan proyectiles (frutas verdes) utilizando una waraca a manera de "batalla ritual". Esta tradición fue observada por el cronista Bernabé Cobo en el Cusco y al respecto menciona: "De las fiestas y sacrificios que hacían en el segundo mes, llamado camay... venían a la plaza los (...) caballeros con vestiduras nuevas, mantas iconadas y plumajes blancos, y con

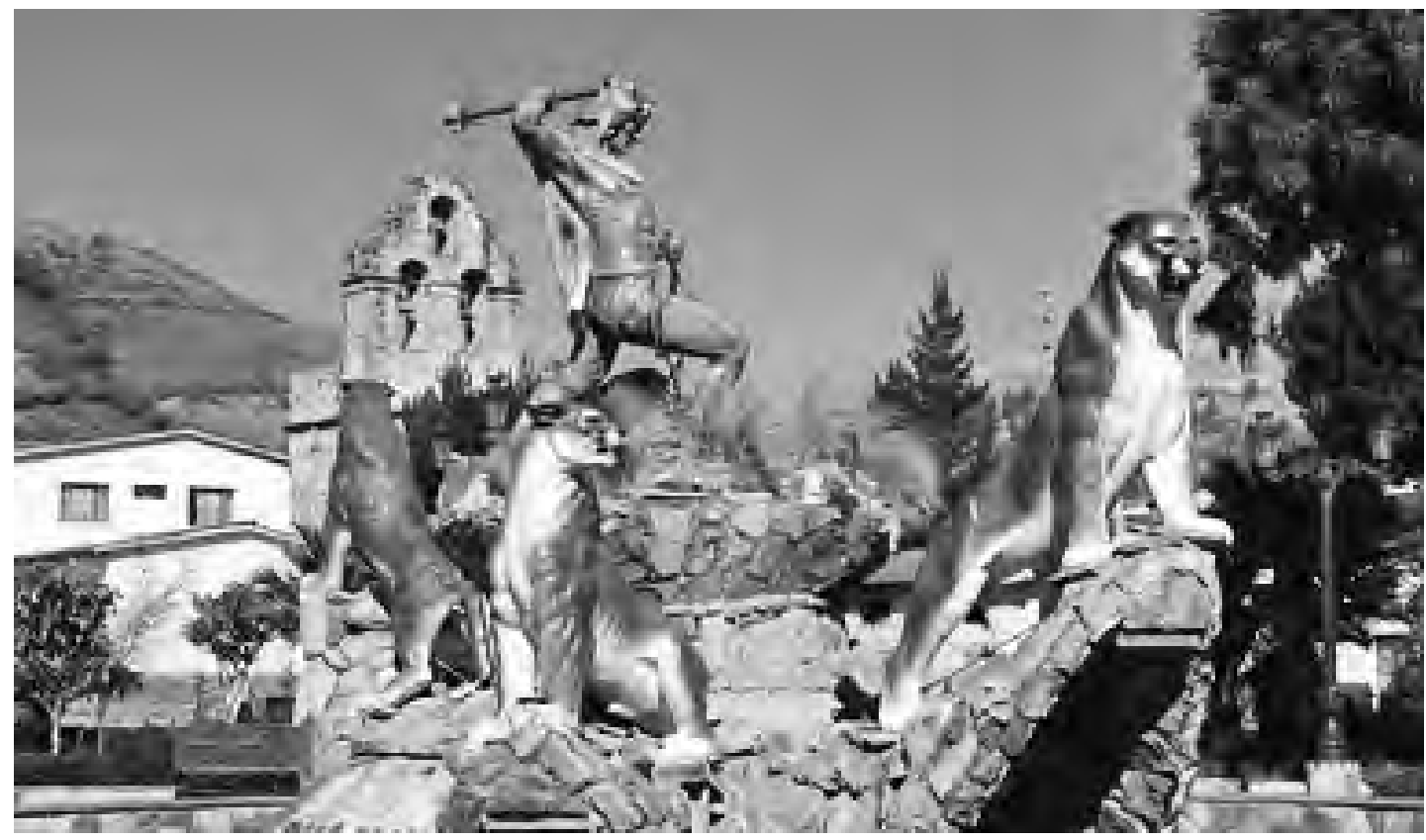

Figura 41: Representación de un guerrero Chanca portando un usqu y rodeado de pumas, "felino sagrado" en la idiosincrasia Chanca. Foto tomada en Andahuaylas. 
sus hondas en las manos. Se dividían en dos bandos y se tiraban con cierta fruta como tunas, al que llamamos pitahayas. Venían algunas veces a las manos a probar fuerzas hasta que el Inca se levantaba y ponía en paz, hacían esto, para que se fuesen conocidos los más valientes y de más fuerza" (Cobo 1964 [1653] :169). De esta manera la ideología ancestral Chanca aún se mantiene enraizada en los pobladores del bajo pampas.

La presencia Inca en el valle de Chumbes impone su cultura, y la ideología Chanca cede sus dominios a este último; quedando como testigos materiales los ushnus de Huayna Pizarro (Figura 40), Pumaqawanqa y Torrechayoq (Cavero 2010, García 2012). En tiempo de la colonia la religiosidad prehispánica (Chanca-Inca) confirió su lugar al establecimiento de templos en cada poblado, siendo el más importante el de la virgen de Santa Isabel en Chumbes -que fue erigido sobre un centro religioso de marcada importancia que data del Periodo Formativo- y la virgen del Carmen en Ccaccamarca.

\section{INTERPRETACIÓN Y CONCLUSIONES}

Nuestra investigación se basa principalmente en el estudio de nueve sitios del Periodo Intermedio Tardío ubicados en la microcuenca del río Qaqamarca, distrito de Ocros (figuras 1-2). La información que presentamos es recurrente a lo que se sabe para la cuenca del río Pampas, sin embargo, aún existen dificultades para definir cabalmente la sucesión de las ocupaciones humanas en el tiempo y el espacio dentro del área geográfica de la cuenca baja del río Pampas; además el estudio que mostramos está supeditado a información empírica superficial basado en material cultural y patrón arquitectónico. Y más aún si tratamos de la ocupación Chanca, que sigue siendo desconocido y por ende requiere un análisis exhaustivo. Todavía queda mucho por investigar en esta parte de la región ayacuchana, y creemos que los datos advertidos se hallan en un nivel especulativo pero suficiente para esbozar las características específicas de los chancas hasta la espera de mayores datos.

Las evidencias arqueológicas del distrito de Ocros resume importantes sucesos que acontecieron durante la ocupación post Wari, donde los chancas salen a la palestra tomando consigo los lugares mejor protegidos y siempre relacionados con la cuenca del Pampas. Los cronistas entendieron la historia como una sucesión de guerras y conquistas, donde la población prehispánica fue descrita como salvaje y guerrera. Algo de esto ocurrió con los Chancas, los cronistas solo se fijaron en su aspecto militar y olvidaron comentar otros aspectos de su cultura, como los conocimientos agrícolas, ideológicos, tecnológicos, etc.
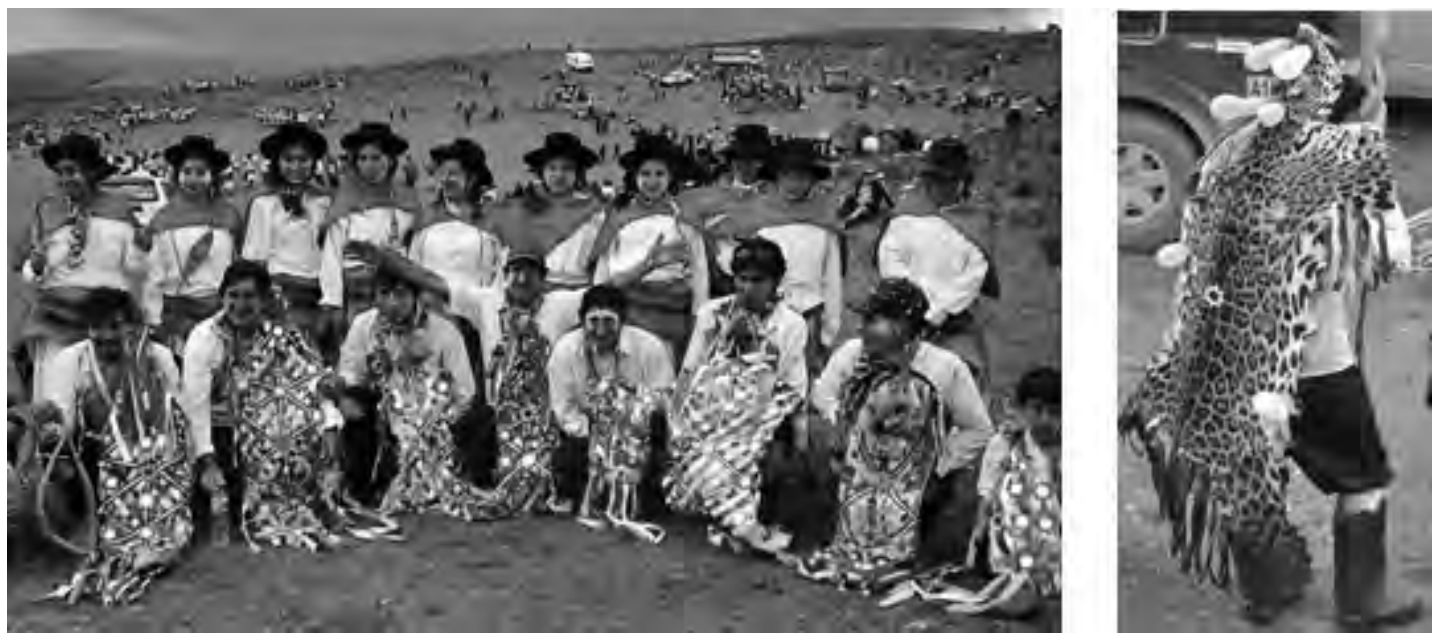

Figuras 42-43. Traje típico de los portadores culturales (varón y mujer) del carnaval, se puede apreciar la esencia de la cultura ancestral andina. Se nota el usqu del zorro y otorongo y, la waraka para el siqullu. 
El análisis de las manifestaciones culturales registradas en los sitios del Periodo Intermedio Tardío del valle de Chumbes, sugiere que nos hallamos frente a una cultura bastante compleja. Los sitios fueron intensamente ocupados por los Chancas hasta los primeros años de la conquista incaica. Presentan una arquitectura de planta circular ubicados sobre relieves bastante accidentados y laderas de gran extensión, circundado por pendientes abruptas y protegidas por un sistema defensivo basado en murallas y zanjas. Similar a los distintos asentamientos de la época Chanca situados en la sierra centro-sur del Perú (Lumbreras 1974; González et. al 1987; Valdez y Vivanco 1994; García 2009). Asimismo, los fragmentos de cerámica y artefactos líticos localizados en los espacios residenciales están relacionados a diferentes actividades como: domésticas (preparación de alimentos), alfareras, agrícolas, de caza y de combate, como puntas de proyectil, boleadoras y maqanas. Se adecuaron eficientemente en un medio natural precario y explotaron los recursos a través de estrategias innovadoras que reflejan un conocimiento adecuado de los recursos. Los Chancas no solo fueron grandes guerreros, sino que fue un pueblo de mucha vocación agro-ganadera - heredados de sus antecesores Huarpa y Wari - y desarrollaron redes de intercambio mediante los caminos que los incas aprendieron y supieron manejar.

El paisaje natural en donde se hallan los sitios arqueológicos de Llaqtapata, Qollqe Pedro, Ventanayoq y Llaqtapata II, son estratégicos, defensivos y de difícil acceso; difieren particularmente con los demás sitios registrados en el valle de Chumbes. Estos sitos están estrechamente relacionados a la defensa de su territorio mediante sistemas defensivos comprendidos por murallas y zanjas. Probablemente tuvieron una autonomía en cuanto a la posesión del territorio pero manteniendo coordinación y vigilancia con los asentamientos adyacentes. La ocupación del terreno fue exclusivamente en el Periodo Intermedio Tardío, debido a la poca profundidad del suelo y los rasgos de los recintos no presentan signos de modificación. Asimismo, el patrón constructivo es recurrente para todos los sitios de este periodo, presentando un reducido número de recintos precarios y aglutinados; tal como menciona González et. al (1987), que los Chancas constituyeron poblados con limitado número de habitantes, esto por el abandono de la vida urbana orientado a una vida aldeana-rural, campesina; las edificaciones al interior de las aldeas son similares, siendo imposible identificar diferencias que indiquen barrios residenciales o zonas de producción.

Los sitios de Cuncalla, Mañagua, Huayna Pizarro y Balcón, son aldeas rurales dispersas asociadas a grandes corrales ganaderos, áreas agrícolas y espacios funerarios. Comparte la tradición arquitectónica de planta circular con los demás sitios, pero no muestran fortificaciones artificiales relevantes. Por su correspondiente ubicación se trataría de asentamientos ligados a la explotación de los recursos agrícolas y la crianza de ganados para abastecer la demanda de los habitantes del sitio Llaqtapata, que posiblemente cumplió la función de centro administrativo. Finalmente, sitio Vaca Velana está ubicado en la parte baja del valle, lo que evidencia que los habitantes no abandonaron por completo las áreas ocupadas por su antecesor Wari, sino modificaron el espacio con la incorporación de viviendas de planta circular protegidos por una inmensa zanja y muros perimétricos. Reocuparon las áreas agrícolas que proveían de recursos para su subsistencia; paulatinamente abandonaron este sitio para ocupar las partes altas y cuyas construcciones no sufrieron muchas modificaciones. El material cultural asociado fue el alfar Tanta Orqo, lo que hace suponer que ¿Los habitantes del valle bajo de Chumbes en el Periodo Intermedio Tardío fueron los propios waris? Que apostaron por una vida precaria debido a una inestabilidad social en la que se vivía. Investigaciones futuras esclarecerán este tema.

Los espacios funerarios localizados cerca a los sitios se caracterizan por presentar varios tipos de patrones de enterramiento como chullpas, cámaras funerarias y abrigos rocosos. Las dos primeras son estructuras elaboradas donde probablemente sepultaron a los jefes o gobernantes, no descar- 
tamos la existencia de una estratificación social. Mientras que en los abrigos rocosos enterraron al común de la población mediante entierros colectivos, resaltando la presencia de cráneos con deformaciones fronto-occipital tubular y signos de trepanación, asociados a vasijas y textiles en mal estado de conservación. La muerte para las sociedades prehispánicas fue muy importante, convirtiéndose en ancestro y por ello recibieron un trato especial. Ideológicamente, el respeto a los ancestros y el uso de la indumentaria ancestral heredada por los chancas, queda manifestado en el osqo o usqu que son usadas en las festividades carnestolendas del valle de Chumbes. Estos representan símbolos sagrados que están asociados a la destreza y la habilidad, tal como relatan las crónicas, donde indican que los chancas simbolizaban a los animales andinos, principalmente al puma y el cóndor, y desde luego también a otros animales (Ramos 2002). Con el paso del tiempo se transformó en una celebración de la abundancia y fecundación de la tierra o pacha mama, al coincidir con el tiempo de las lluvias y periodo propicio para el cortejo amoroso, expresado en el canto, baile y especialmente en el pukllay, forma lúdica de acercamiento entre varones y mujeres, y competencia física. Esta tradición trata en general sobre el inicio del ciclo y productivo, la renovación de la naturaleza como de la sociedad colectiva del pueblo.

\section{RECOMENDACIONES}

Los sitios arqueológicos ubicados en la microcuenca del río Qaqamarca están siendo ignorados y a la vez destruidas con la expansión agrícola, explosión demográfica y obras de desarrollo. Esperamos que este artículo sea un aporte al estudio arqueológico del distrito de Ocros y desde esta perspectiva, consideramos que la mejor defensa del patrimonio cultural arqueológico es mediante el catastro e inventario de sitios. Los sitios arqueológicos e históricos del valle de Chumbes presentan una oportunidad para tomar medidas cada vez más indispensables para conservar no solo nuestro pasado sino también nuestro futuro.

\section{Agradecimientos}

A Cirilo Vivanco Pomacanchari por el apoyo y asesoramiento brindado. Un reconocimiento especial a los arqueólogos Joel Cárdenas Martínez, Alex Zamora Vera y Juan Bolívar Huamaní (UNSCH), quienes apoyaron en las salidas a la zona de estudio. A mi hermano Raúl García Reyes y mis padres por todo el apoyo brindado.

\section{BibliografÍA}

BOLÍVAR, Juan

2010 Ubicación y registro de restos arqueológicos en la margen derecha del río Qaqamarca, Ocros-Ayacucho. Tesis de Bachiller en Arqueología. Universidad Nacional de San Cristóbal de Huamanga. Ayacucho.

CAVERO P. Yuri

2010 Inkapamisan: ushnus y santuario Inka en Ayacucho. Universidad Nacional San Cristóbal de Huamanga.

CIEZA DE LEÓN, Pedro

1984 [1533] La Crónica del Perú. Edición de Carmelo Sáez de Santa María. Madrid: Tomo I de "Obras completas". C.S.I.C.

COBO, Bernabé

1964[1653] Historia del Nuevo Mundo. Edición de Francisco Mateos. Madrid: Biblioteca de Autores Españoles. vols. 91 y 92. 


\section{GARCÍA REYES, Anuor Abel}

2009 Reconocimiento arqueológico en la microcuenca del rio Qaqamarca, valle de Ocros - Ayacucho. Tesis de Bachiller en Arqueología. Universidad Nacional de San Cristóbal de Huamanga. Ayacucho.

\section{GARCILAZO DE LA VEGA, Inca}

1963 Comentarios Reales de los Incas. México: Publicaciones de la Universidad de Puebla. Editorial J.M. Cajica, Tomo I, vol. 133.

\section{GUAMAN POMA DE AYALA, Felipe}

1987[1583-1615] Nueva crónica y buen gobierno. Edición de John V. Murra, Rolena Adorno y Jorge L. Urioste. Madrid: Vols. 29A, B y C de "Crónicas de América". Historia 16.

\section{GONZÁLEZ CARRÉ, Enrique}

1982 Historia prehispánica de Ayacucho, Los Chankas y otras naciones. Perú: Universidad Nacional de San Cristóbal de Huamanga.

2004 “Los Señoríos Chancas: Historia Mitos y Leyendas”. Perú: En BIRA, № 31, pp. 67-84.

GONZÁLEZ CARRÉ, Enrique; POZZI ESCOT, Denise y Cirilo VIVANCO P.

1987 Los Chancas: cultura material. Perú: Editorial de la Universidad Nacional de San Cristóbal de Huamanga.

1988 El área histórica Chanka.

\section{KAULICKE, Peter}

1997 “La Muerte en el Antiguo Perú, Contextos y Conceptos Funerarios". En Boletín de Arqueología PUCP, vol. № 01.

LAVALLEÉ, Danielle y Michele JULIEN

1983 Asto: Curacazgo Prehispánico en los Andes Centrales. Ediciones IEP, Industrial Grafica S.A.

LUMBRERAS, Luís

1974 Las fundaciones de Huamanga: Hacia una Prehistoria de Ayacucho. Club de Huamanga Editores.

MATOS, Ramiro

1999 “La cerámica Inca. Paqchas y cochas". Los Incas, Arte y Símbolos. Colección Arte y Tesoros del Perú del Banco de Crédito del Perú. Lima. pp. 109-165.

MONZÓN, LUIS DE, y otros

1965[1586] "Descripción de la tierra del repartimiento de los Rucanas Antamarcas de la Corona Real, jurisdicción de la ciudad de Guamanga”. En: Relaciones Geográficas de Indias, Tomo I, Marcos Jiménez de la Espada, ed. Madrid: Biblioteca de autores españoles. pp.237-248

OCHANTE, Celestino

2000 Prospección arqueológica en el Distrito de Concepción-Vilcashuamán. Tesis de Bachiller en Arqueología. Universidad Nacional de San Cristóbal de Huamanga. Ayacucho. 
RAIMONDI, Antonio

1942(1858) Notas de Viajes para su obra EL PERÚ: Viaje al Cuzco y Valle de Santa Ana, Ayacucho, Huancavelica y Pisco. Primer volumen. Perú: Imprenta Torres Aguirre

RAMOS, Luis

2002 "El choque de los Incas con los Chancas en la iconografía de vasijas lígneas coloniales". España. Revista Española de Antropología Americana. № 32, pp. 243-265.

SANTILLANA, Julián

1999 “Andenes, Canales y Paisaje”. Los Incas Artes y símbolos. Fondo Editorial Banco de Crédito del Perú.

VALDEZ, Julio Ernesto

2003 “Pueblos del Periodo Intermedio Tardío”. Revista Arqueológica Warpa, № 03. Huanta-Ayacucho.

VALDEZ, Lidio y Cirilo VIVANCO

1994 “Arqueología de la Cuenca del Qaracha, Ayacucho". En: Latin American Antiquity, Vol. 5, No. 2, pp. 144-157.

VIVANCO, Cirilo

1999 "Raqaraqaypata y Ñaupallaqta, dos sitios de la época Chanca en el área sur de Ayacucho". En XII Congreso Peruano del Hombre y la Cultura Andina, Tomo II, UNSCH-Ayacucho.

2004 “Tiempos de Purunrunas en la Cuenca de Qaracha, Ayacucho. La Violencia en la época Pre Hispánica Tardía”. Investigaciones en Ciencias Sociales № 2. Revista del Museo de Investigaciones. Ayacucho, pp.

WIENER, Charles

1993[1880] Perú y Bolivia, relato de viaje. Instituto Francés de Estudios Andinos y Universidad Nacional Mayor de San Marcos. 